\title{
Article \\ Crystallization, Luminescence and Cytocompatibility of Hexagonal Calcium Doped Terbium Phosphate Hydrate Nanoparticles
}

\author{
Jaime Gómez-Morales ${ }^{1}$ * $\mathbb{D}$, Raquel Fernández-Penas ${ }^{1}$, Ismael Romero-Castillo ${ }^{1}$, Cristóbal Verdugo-Escamilla ${ }^{1} \mathbb{D}_{\text {, }}$ \\ Duane Choquesillo-Lazarte ${ }^{1} \mathbb{D}$, Annarita $D^{\prime}$ Urso $^{2}$, Maria Prat ${ }^{2,3,4,5, * \mathbb{D}}$ and Jorge Fernando Fernández-Sánchez ${ }^{6} \mathbb{D}$ \\ 1 Laboratorio de Estudios Cristalográficos, IACT, CSIC-UGR, Avda. Las Palmeras, nº 4, 18100 Granada, Spain; \\ raquel@lec.csic.es (R.F.-P.); ismaelrc92@gmail.com (I.R.-C.); cristobal.verdugo@csic.es (C.V.-E.); \\ duane.choquesillo@csic.es (D.C.-L.) \\ 2 Dipartimento di Scienze della Salute, Università del Piemonte Orientale, Via Solaroli, 17, 28100 Novara, Italy; \\ annarita.durso@uniupo.it \\ 3 Centro di Biotecnologie per la Ricerca Medica Applicata (BRMA), Via Solaroli 17, 28100 Novara, Italy \\ 4 Consorzio Interuniversitario per Biotecnologie (CIB), Località Padriciano 99, 34149 Area di Ricerca, Italy \\ 5 Consorzio Interuniversitario Nazionale per la Scienza e Tecnologia dei Materiali (INSTM), 28100 Novara, Italy \\ 6 Department of Analytical Chemistry, Faculty of Sciences, University of Granada, Avda. Fuentenueva s/n, \\ 18071 Granada, Spain; jffernan@ugr.es \\ check for \\ * Correspondence: jaime@lec.csic.es (J.G.-M.); maria.prat@med.uniupo.it (M.P.); Tel.: +34-958-230000 (J.G.-M.); \\ +39-0321-660662(M.P.)
}

updates

Citation: Gómez-Morales, J.;

Fernández-Penas, R.; Romero-Castillo, I.; Verdugo-Escamilla, C.;

Choquesillo-Lazarte, D.; D’Urso, A.;

Prat, M.; Fernández-Sánchez, J.F.

Crystallization, Luminescence and

Cytocompatibility of Hexagonal

Calcium Doped Terbium Phosphate

Hydrate Nanoparticles. Nanomaterials

2021, 11, 322. https://doi.org/

$10.3390 /$ nano11020322

Academic Editor:

Marie-Helene Delville

Received: 24 December 2020

Accepted: 21 January 2021

Published: 27 January 2021

Publisher's Note: MDPI stays neutral with regard to jurisdictional claims in published maps and institutional affiliations.

Copyright: (C) 2021 by the authors Licensee MDPI, Basel, Switzerland. This article is an open access article distributed under the terms and conditions of the Creative Commons Attribution (CC BY) license (https:// creativecommons.org/licenses/by/ $4.0 /)$.

\begin{abstract}
Luminescent lanthanide-containing biocompatible nanosystems represent promising candidates as nanoplatforms for bioimaging applications. Herein, citrate-functionalized calcium-doped terbium phosphate hydrate nanophosphors of the rhabdophane type were prepared at different synthesis times and different $\mathrm{Ca}^{2+} / \mathrm{Tb}^{3+}$ ratios by a bioinspired crystallization method consisting of thermal decomplexing of $\mathrm{Ca}^{2+} / \mathrm{Tb}^{3+} /$ citrate/phosphate/carbonate solutions. Nanoparticles were characterized by XRD, TEM, SEM, HR-TEM, FTIR, Raman, Thermogravimetry, inductively coupled plasma spectroscopy, thermoanalysis, dynamic light scattering, electrophoretic mobility, and fluorescence spectroscopy. They displayed ill-defined isometric morphologies with sizes $\leq 50 \mathrm{~nm}$, hydration number $\mathrm{n} \sim 0.9$, tailored $\mathrm{Ca}^{2+}$ content (0.42-8.11 wt\%), and long luminescent lifetimes (800-2600 $\mu \mathrm{s})$. Their relative luminescence intensities in solid state are neither affected by $\mathrm{Ca}^{2+}$, citrate content, nor by maturation time for $\mathrm{Ca}^{2+}$ doping concentration in solution below $0.07 \mathrm{M} \mathrm{Ca}^{2+}$. Only at this doping concentration does the maturation time strongly affect this property, decreasing it. In aqueous suspensions, neither $\mathrm{pH}$ nor ionic strength nor temperature affect their luminescence properties. All the nanoparticles displayed high cytocompatibility on two human carcinoma cell lines and cell viability correlated positively with the amount of doping $\mathrm{Ca}^{2+}$. Thus, these nanocrystals represent promising new luminescent nanoprobes for potential biomedical applications and, if coupled with targeting and therapeutic moieties, they could be effective tools for theranostics.
\end{abstract}

Keywords: terbium phosphates; calcium doped; citrate; nanoparticles; luminescence; cytocompatibility

\section{Introduction}

Luminescent nanoparticles are excellent optical probes for uses in biological imaging since they provide the essential fluorescent contrast to analyze and study cells and tissues [1]. Different luminescent labeling agents, mainly organic dyes, and nanomaterials including semiconductor quantum dots, nanodiamonds, gold nanoparticles [2-4], several nanostructures labeled with organic dyes [5], and more recently calcium phosphate apatite nanoparticles (nAp) both labeled with organic dyes [6] or doped with luminescent lanthanides $\left(\operatorname{Ln}^{3+}\right)$ ions $[7,8]$, have been proposed for these applications. The main limitation of organic dyes is photobleaching [5], while the use of quantum dots is controversial due 
to their cytotoxicity [9]. In the last years lanthanide orthophosphates $\left(\mathrm{LnPO}_{4}, \mathrm{Ln}^{3+}=\mathrm{Eu}^{3+}\right.$, $\mathrm{Tb}^{3+}, \mathrm{Ce}^{3+}, \mathrm{Y}^{3+} \ldots$ ) started to attract much attention because they combine the very low solubility and high thermal conductivity of the metal phosphates as host matrices with the favorable features of the luminescent lanthanide ions, such as sharp emission bands, Stokes shift of hundreds of nanometers, and luminescence lifetimes of the order of milliseconds. For all the above reasons they find applications as phosphors, catalysts, sensors and heatresistant materials [10]. In addition, they exhibit low cytotoxicity, high photostability, and resistance to photobleaching, thus being good optical nanoprobes for bioimaging [11-13]. $\mathrm{LnPO}_{4} \cdot \mathrm{nH}_{2} \mathrm{O}(n=0-2)$ presents five polymorphic modifications, among which the low temperature hydrated phase with hexagonal structure is known as raphdophane [14,15]. In respect to $\mathrm{Ln}^{3+}$-doped $\mathrm{nAp}$, the $\mathrm{LnPO}_{4} \cdot \mathrm{nH}_{2} \mathrm{O}$ system presents the main advantage that at low temperatures $\left(<100{ }^{\circ} \mathrm{C}\right)$ raphdophane is usually the only precipitated phase from aqueous solutions [15]. In calcium phosphate solutions, in contrast, several polymorphs can eventually appear including amorphous calcium phosphate (ACP), dicalcium phosphate dihydrate (DCPD, brushite), octacalcium phosphate (OCP), and Ap [16-18]. The synthetic methods to prepare $\mathrm{LnPO}_{4}$ nanocrystals include hydrothermal crystallization [19-21], microwave heating [22], ultrasounds [23], oil bath [24], sol-gel combined with electrospinning [25], slow crystallization using surfactants [26], or the layer-by layer adsorption followed by the reaction and crystallization at room temperature [27].

Among lanthanides, $\mathrm{Eu}^{3+}$ and $\mathrm{Tb}^{3+}$ started to be used in various host structures using different excitation wavelength in the $\mathrm{UV}$ region, with main emission bands in the Visible spectral region. Concerning $\mathrm{LnPO}_{4}$, the $\mathrm{TbPO}_{4} \cdot \mathrm{nH}_{2} \mathrm{O}$ raphdophane nanorods were excited in the UV region at either $270,312,350$ or $370 \mathrm{~nm}$, and in the visible region at $482 \mathrm{~nm}$, resulting in similar emission spectra, and yielding a characteristic green emission, due to ${ }^{5} \mathrm{D}_{4}{ }^{7} \mathrm{~F}_{5}$ transition at $546 \mathrm{~nm}$ emission of $\mathrm{Tb}^{3+}$ [28]. Doping with $\mathrm{Eu}^{3+}$ allows the preparation of $\mathrm{Eu}^{3+}: \mathrm{TbPO}_{4}$ of hexagonal form with improved energy transfer efficiency between $\mathrm{Tb}^{3+}$ and $\mathrm{Eu}^{3+}$ and non-cytotoxicity on HeLa cells [13]. Recently, our group used citrate (cit) to prepare new luminescent cit-coated $\mathrm{Ca}^{2+}: \mathrm{EuPO}_{4} \cdot \mathrm{nH}_{2} \mathrm{O}$ (with $\mathrm{n}$ ) by the method of thermal decomplexing of $\mathrm{M}^{(2+/ 3+)} / \mathrm{Ca}^{2+} / \mathrm{cit} /$ phosphate/carbonate solutions $\left(\mathrm{M}^{(2+/ 3+)}\right.$, metallic ions) [29]. The method was initially developed to precipitate monodisperse biomimetic apatites [30] and carbonated apatite nanocrystals, both undoped and doped with transition metals [31,32], and $\mathrm{Eu}^{3+}$ [8]. In this method citrate ions played an active role in the nucleation and growth steps, and remained adsorbed on the nanoparticles surface [33], a feature presented in bone apatite nanocrystals [34]. The new luminescent cit- $\mathrm{Ca}^{2+}: \mathrm{EuPO}_{4} \cdot \mathrm{H}_{2} \mathrm{O}$ nanomaterials proved to be fully cytocompatible against GTL-16 human carcinoma cells and showed an improved cytocompatibility as the $\mathrm{Ca}^{2+}$ content increased when contacted with the more sensitive m17.ASC murine mesenchymal stem cells, thus proving to be suitable for bioimaging and cell labeling.

The aim of the present work is to employ the same bioinspired route to prepare cit$\mathrm{Ca}^{2+}: \mathrm{TbPO}_{4} \cdot \mathrm{nH}_{2} \mathrm{O}$ nanocrystals with tuned luminescence and high cytocompatibility, in the assumption that the presence of $\mathrm{Ca}^{2+}$ in the structure and citrate adsorbed on these luminescent solids must be beneficial from the point of view of the cytocompatibility required in bioimaging.

\section{Materials and Methods}

\subsection{Materials and Precipitation Method}

For the experiments the following reagents were purchased from Sigma-Aldrich (St Louis, MO, USA): Terbium (III) chloride anhydrous $\left(\mathrm{TbCl}_{3}, 99.9 \%\right.$ pure, trace metals), sodium citrate tribasic dihydrate $\left(\mathrm{Na}_{3}(\mathrm{cit}) \cdot 2 \mathrm{H}_{2} \mathrm{O}\right.$, where cit $=$ citrate $=\mathrm{C}_{6} \mathrm{H}_{5} \mathrm{O}_{7}$, ACS reagent, $\geq 99.0 \%$ pure), calcium chloride dihydrate $\left(\mathrm{CaCl}_{2} \cdot 2 \mathrm{H}_{2} \mathrm{O}\right.$, Bioxtra, $\geq 99.0 \%$ pure), and sodium phosphate dibasic $\left(\mathrm{Na}_{2} \mathrm{HPO}_{4}, \mathrm{ACS}\right.$ reagent, $\geq 99.0 \%$ pure). Sodium carbonate monohydrate $\left(\mathrm{Na}_{2} \mathrm{CO}_{3} \cdot \mathrm{H}_{2} \mathrm{O}\right.$, ACS reagent, $99.5 \%$ pure) and hydrochloric acid $(\mathrm{HCl}$, ACS reagent, $37 \mathrm{wt} \%$ in $\mathrm{H}_{2} \mathrm{O}$ ) were provided by Merck (Darmstadt, Germany) and Panreac 
(Barcelona, Spain), respectively. Solutions were prepared with ultrapure deionized water $\left(0.22 \mu \mathrm{S}, 25^{\circ} \mathrm{C}\right.$, Milli-Q, Millipore, Burlington, MA, USA).

The synthesis of nanocrystals was carried out by the already established method of thermal decomplexing of $\mathrm{M}^{(2+/ 3+)} / \mathrm{Ca}^{2+} / \mathrm{cit} /$ phosphate/carbonate solutions [29], using $\mathrm{Tb}^{3+}$ as lanthanide ion $(y=0.09,0.07,0.05$ and $0.03 \mathrm{M})$ and increasing concentrations of doping $\mathrm{Ca}^{2+}$ in the solution $(x=0.01 \mathrm{M}, 0.03,0.05$, and $0.07 \mathrm{M})$ to set $x+y=0.1 \mathrm{M}$. The experiments lasted $4 \mathrm{~h}, 24 \mathrm{~h}$, and $96 \mathrm{~h}$. Some of them were matured for 7 days. The precipitates were subjected to washing by centrifugation with ultrapure water (6 cycles, $9000 \mathrm{rpm}, 9 \mathrm{~min}$ each) and freeze-dried overnight at $-50{ }^{\circ} \mathrm{C}$ under vacuum ( $3 \mathrm{mbar}$ ).

\subsection{Physico-Chemical Characterization of Solid Nanoparticles}

As-prepared powders were analyzed by different techniques, as it is described below:

$X$-ray powder diffraction (XRD) patterns were recorded using a diffractometer PANAlytical MPD (PANAlytical, Almelo, The Netherlands) with a Bragg-Brentano parafocusing geometry and $\mathrm{Cu} \mathrm{K} \alpha$ radiation. Data processing of most matured samples was carried out with software TOPAS 6.0 (Coelho Software, Brisbane, Australia) [35]. The contribution of the isotropic peak broadening due to domain size was modeled using the "CS_L" TOPAS macro based on the Scherrer approximation, and considering the instrumental contribution from a measurement of $\mathrm{LaB}_{6}$ standard (NIST SRM 660c).

TEM observations were performed with a TEM Libra 120 Plus (EELS) instrument at $80 \mathrm{kV}$ (Carl Zeiss, Jena, Germany). Prior to observation samples were dispersed in absolute ethanol $(\geq 99.8 \% v / v)$ and deposited on copper microgrids coated with FORMVAR carbon film. HRTEM analysis were done with a TITAN G2 60-300 FEI Instrument (FEI, Hillsboro, OR, USA) operating at $300 \mathrm{kV}$, equipped with EDX Super X detector to perform microanalysis, and STEM type HAADF.

Fourier transform infrared spectra (FTIR) were recorded in transmittance mode within the wavelength range from $4000 \mathrm{~cm}^{-1}$ to $400 \mathrm{~cm}^{-1}$ using a Perkin-Elmer Spectrum One FTIR spectrometer (Perkin Elmer, Shelton, WA, USA). Pellets with $\sim 1 \mathrm{wt} \%$ sample in anhydrous $\mathrm{KBr}$ were prepared and pressed with a hydraulic pump at 10 tons. Pure $\mathrm{KBr}$ pellets were used to record the background. Raman spectra were recorded with a LabRAM HR spectrometer (Jobin-Yvon, Horiba, Tokyo, Japan). The excitation line was provided by a diode laser emitting at a wavelength of $532 \mathrm{~nm}$ while a Peltier cooled charge-couple device $(C C D)(1064 \times 256$ pixels) was used as a detector.

Crystal size distribution (CSD) and electrophoretic mobility ( $\zeta$-potential) were analyzed with a Zetasizer Nano ZS analyzer (Malvern Instruments Ltd., Malvern, UK) in aqueous suspensions $\left(\sim 0.5 \mathrm{mg} / \mathrm{mL}, 25^{\circ} \mathrm{C}\right)$ contained in disposable polystyrene cuvettes. For $\zeta$-potential versus $\mathrm{pH}$ measurements the MPT-2 autotitrator (Malvern Instruments Ltd., Malvern, UK) was employed to adjust the $\mathrm{pH}$ of the suspensions. Diluted $\mathrm{HCl}$ and $\mathrm{NaOH}$ solutions ( 0.25 and $0.1 \mathrm{M}$, respectively) were used as titration agents without any additional electrolyte.

Elemental analysis of $\mathrm{Tb}$ was carried out by inductively coupled plasma mass spectroscopy (ICP MS) using a Perkin Elmer NexION 300D ICP Mass spectrometer (Perkin Elmer). Ca and P were analyzed with Perkin Elmer ICP-OES OPTIMA 8300 spectrometer (Perkin Elmer); $\mathrm{C}$ and $\mathrm{H}$ were determined by thermoanalysis using Thermo Scientific ${ }^{\mathrm{TM}}$ FLASH 2000 CHNS/O Analyzer of Thermo Fisher Scientific (Waltham, MA, USA). TGA analyses were performed with a thermogravimetric analyzer TGA-50H model (Shimadzu, Tokyo, Japan). Samples were weighted in a platinum crucible and heated from room temperature $\left(\sim 28^{\circ} \mathrm{C}\right)$ to $950{ }^{\circ} \mathrm{C}$ under $50 \mathrm{~mL} / \mathrm{min}$ air flow with a heating rate of $20^{\circ} \mathrm{C} / \mathrm{min}$.

\subsection{Luminescence Spectroscopy}

Excitation and emission spectra of both powder and aqueous suspension $\mathrm{mg} / \mathrm{mL}$ samples, the latter being at $\sim 0.5 \mathrm{mg} / \mathrm{mL}$, were recorded using a Cary Eclipse Varian Fluorescence Spectrophotometer (Varian Australia, Mulgrave, Australia) using $\lambda_{\text {exc }}=375 \mathrm{~nm}$, $\lambda_{\mathrm{em}}=545 \mathrm{~nm}, 0.120 \mu \mathrm{s}$ delay time (td) and $5 \mathrm{~ms}$ gate time $\left(\mathrm{t}_{\mathrm{g}}\right)$; photomultiplier voltage 
of $470 \mathrm{~V}$ and slit width $\mathrm{exc}_{\mathrm{em}} 5 / 5 \mathrm{~nm}$ for powder samples and photomultiplier voltage of

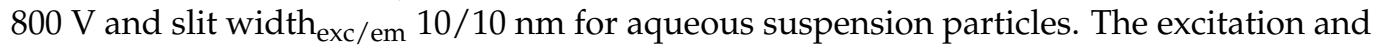
emission spectra were recorded within the range $250-500 \mathrm{~nm}$ and 500-750 $\mathrm{nm}$, respectively. Lifetime $(\tau)$ measurements were also recorded by a Cary Eclipse Varian Fluorescence Spectrophotometer (Varian Australia, Mulgrave, Australia) using $\lambda_{\text {exc } / \mathrm{em}}=375 / 475 \mathrm{~nm}, 100 \mu \mathrm{s}$ delay time $\left(t_{d}\right), 0.010 \mathrm{~ms}$ gate time $\left(t_{g}\right)$, photomultiplier voltage of $600 \mathrm{~V}$, slit width exc/em $10 / 10 \mathrm{~nm}$ and 100 cycles.

For solid sample analysis, a Cary Eclipse Solid Sample Holder (https: / / www.agilent.com/ en/product/molecular-spectroscopy/fluorescence-spectroscopy/fluorescence-accessories / caryeclipse-solid-sample-holder) was used to allow the measuring at the optimum angle and to minimize the effect of the thickness.

Concerning the dispersity of the measurements, they are not shown in the figures due to their lower value. In all the case the RSD (relative standard deviation) were lower than $2 \%(n=3)$.

\subsection{Cytocompatibility Tests}

Nanocrystal cytocompatibility was tested on two cell lines: GTL-16 (a human gastric carcinoma cell line) and A549 (a human lung adenocarcinoma cell line). Then, $24 \mathrm{~h}$ after seeding cells (12,000 GTL-16 and 5000 A549 cells/well in 96-well plates), different concentrations of the differentially doped $\left(x=0.01,0.03,0.05,0.07 \mathrm{M} \mathrm{Ca}^{2+}\right)$ nanoparticles, ranging from 0.1 to $100 \mathrm{mg} / \mathrm{mL}$, were added in $100 \mathrm{~mL}$ of fresh medium. Hydrogen peroxide $(1 \mathrm{mM})$ was used as control of toxicity. After $72 \mathrm{~h}$ incubation, cell viability was evaluated by the 3-(4,5-Dimethylthiazol-2-yl)-2,5-diphenyltetrazolium bromide) (MTT, Sigma) colorimetric assay. Briefly, $20 \mathrm{~mL}$ of MTT solution ( $5 \mathrm{mg} / \mathrm{mL}$ in a PBS solution) were added to each well and the plate was incubated at $37^{\circ} \mathrm{C}$ for $3 \mathrm{~h}$. After the removal of the solution, $125 \mathrm{~mL}$ of isopropanol, $0.2 \mathrm{M} \mathrm{HCl}$ was added to dissolve formazan crystals. One hundred $\mathrm{mL}$ were then removed carefully, and the optical density was measured in a multiwell reader (2030 Multilabel Reader Victor TM X4, Perkin Elmer) at $570 \mathrm{~nm}$. Viability of parallel cultures of untreated cells was taken as $100 \%$ viability, and values obtained from cells undergoing the different treatments were referred to this value. Experiments were performed 3 times using 3 replicates for each sample. Data were statistically analyzed and are expressed as mean \pm standard deviation. Statistical analyses were performed using a oneway ANOVA with Bonferroni's post-hoc test for grouped analyses using GraphPad Prism version 4.03 for Windows, GraphPad Software (GraphPad Prism, San Diego, CA, USA). Differences at $p<0.05$ were considered to be statistically significant.

\section{Results}

\subsection{Structural, Physicochemical, Morphological Characteristics, and Colloidal Stability of} Solid Nanoparticles

The XRD patterns of the solids precipitated for increasing concentration of $\mathrm{Ca}^{2+}(x$, from $0.01 \mathrm{M}$ to $0.07 \mathrm{M}$ ) and increasing maturation times (from 4 to $96 \mathrm{~h}$ ) are reported in Figure 1. In particular, the patterns showing the distinguishing reflections of the hexagonal (raphdophane) phase identified as $\mathrm{TbPO}_{4} \cdot \mathrm{nH}_{2} \mathrm{O}$, space group $\mathrm{P}_{1} 21$ (PDF 20 1244) are displayed in panels a-d. At $x=0.01 \mathrm{M} \mathrm{Ca}^{2+}$ this is the only crystalline phase identified. The main reflections of this phase are located at $2 \theta 14.85^{\circ}(100), 20.43^{\circ}(101), 25.91^{\circ}(110)$, $30.02^{\circ}(200), 32.10^{\circ}(102), 38.72^{\circ}(112), 42.70^{\circ}(003), 48.10^{\circ}(301), 49.63^{\circ}(212), 53.2^{\circ}(203)$, and $54.5^{\circ}$ (302). Other minor reflections (non-indexed) appear beyond $2 \theta 55^{\circ}$. These latter peaks are not shown in the PDF 20-1244 card, but are similar to those appearing in the PDF 20-1044 card corresponding to the raphdophane structure in the $\mathrm{EuPO}_{4} \cdot \mathrm{H}_{2} \mathrm{O}$. In addition, small differences in $2 \theta$ positions are found between the two patterns because some peak assignments in PDF file 201244 are affected with errors $\geq 0.2^{\circ}$. When $\mathrm{x} \geq 0.03 \mathrm{M} \mathrm{Ca}^{2+}$ (Figure $1 b-d)$, however, an additional phase started to crystallize. The reflections of this phase at $\sim 27^{\circ}$ and $32.8^{\circ}$ are assigned to $\mathrm{CaCO}_{3}$ vaterite (PDF 33-0268), possibly doped with terbium. The presence of vaterite is more evident at $x=0.05$ and $0.07 \mathrm{M} \mathrm{Ca}^{2+}$. Thus, this 
compound becomes stable in calcium-rich medium due to the presence of residual $\mathrm{CO}_{3}{ }^{2-}$ in the crystallizing solutions. Nevertheless, its presence does not represent a problem concerning biomedical uses since this polymorph of $\mathrm{CaCO}_{3}$ is biocompatible [36]. At $0.07 \mathrm{M} \mathrm{Ca}^{2+}$ we found a slightly different phase evolution with time. At $4 \mathrm{~h}$, the bulging of the baseline is characteristic of an amorphous phase, probably of terbium phosphate, whereas at $24 \mathrm{~h}$ the reflections of the raphdophane phase started to emerge from the bulging baseline. In none of the experiments have we detected the presence of any calcium phosphate phase.
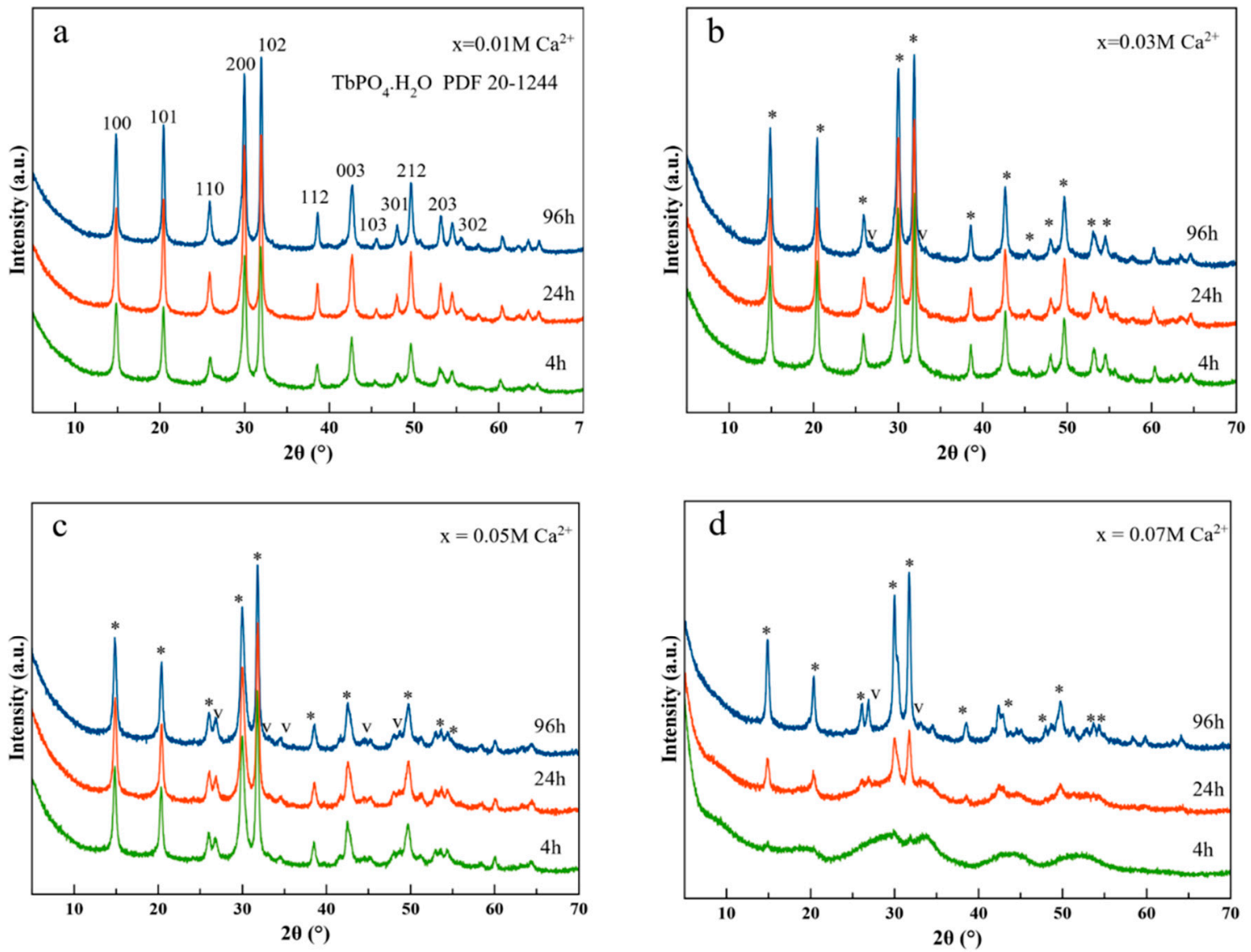

Figure 1. Evolution of XRD patterns with maturation time (4h, green; $24 \mathrm{~h}$, red; $96 \mathrm{~h}$, blue) of samples precipitated from $\mathrm{Ca}^{2+} / \mathrm{Tb}^{3+} / \mathrm{cit} /$ phosphate/carbonate solutions in presence of increasing concentrations of $\mathrm{Ca}^{2+}:(\mathbf{a}) x=0.01 \mathrm{M} \mathrm{Ca}{ }^{2+} ;(\mathbf{b})$ $x=0.03 \mathrm{M} \mathrm{Ca}^{2+} ;$ (c) $x=0.05 \mathrm{M} \mathrm{Ca}^{2+}$, and (d) $x=0.07 \mathrm{M} \mathrm{Ca}^{2+} .{ }^{*}$ hexagonal phase $\mathrm{TbPO}_{4} \cdot \mathrm{nH}_{2} \mathrm{O}$ PDF $20-1244$.

The microstructural study of $96 \mathrm{~h}$ samples was performed by analysis of the full XRD pattern, excluding the reflections of vaterite (Figure 2). Results show isometric crystalline domains whose average Scherrer diameters were $37.6 \pm 0.2 \mathrm{~nm}$ for the less $\mathrm{Ca}^{2+}$-doped sample (Figure 2a), $28.6 \pm 0.2 \mathrm{~nm}$ for $x=0.03 \mathrm{M} \mathrm{Ca}^{2+}$ (Figure 2b), $24.9 \pm 0.2$ for $x=0.05$ (Figure 2c), and $30.2 \pm 0.1$ for $x=0.07 \mathrm{M} \mathrm{Ca}^{2+}$ (Figure 2d), respectively.

TEM observations of these precipitates show nanocrystals with ill-defined shapes and aspect ratios close to 1 (Figure $3 \mathrm{a}-\mathrm{c}$ ). In contrast to what has been reported for cit$\mathrm{Ca}^{2+}: \mathrm{EuPO}_{4} \cdot \mathrm{H}_{2} \mathrm{O}$ nanoparticles, no appreciable dependence of their morphology with $\mathrm{Ca}^{2+}$ doping was found [29]. 

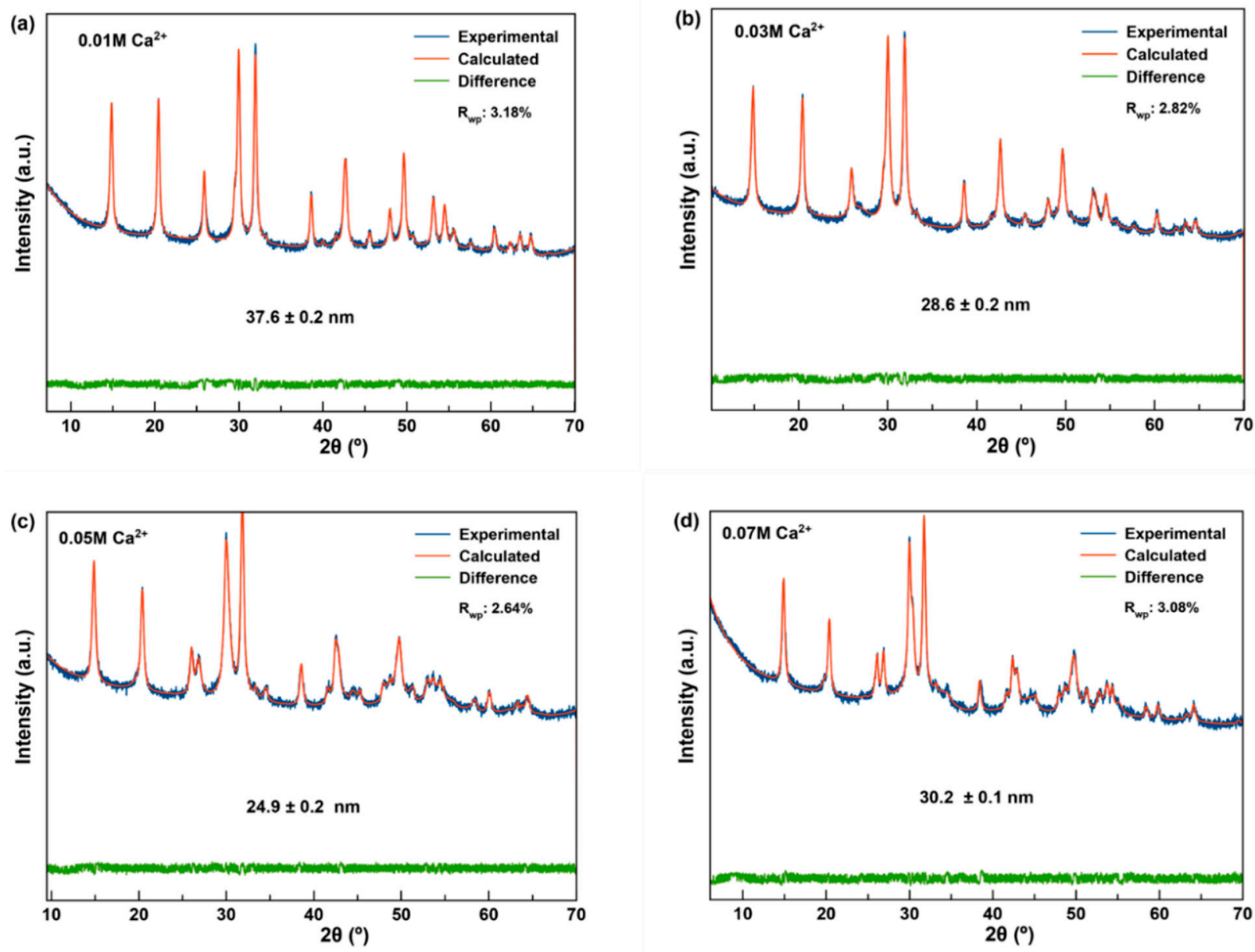

Figure 2. Crystalline domain sizes of $\mathrm{Ca}^{2+}: \mathrm{TbPO}_{4} \cdot \mathrm{nH}_{2} \mathrm{O}$ nanoparticles prepared with, (a) $x=0.01 \mathrm{M}$; (b) $x=0.03 \mathrm{M}$; (c) $x=0.05 \mathrm{M}$ and (d) $x=0.07 \mathrm{M} \mathrm{Ca}^{2+}$ for $96 \mathrm{~h}$, calculated by analysis of the full XRD pattern using TOPAS 6.0. The two XRD vaterite reflections are excluded. $\mathrm{R}_{\mathrm{wp}}$, weighted profile R-factor as described in Young [37].

The sizes deduced on the basis of either TEM $(29 \pm 5,28 \pm 3,33 \pm 6$, Figure $3 a-c)$ or $\operatorname{SEM}\left(x=0.07 \mathrm{M} \mathrm{Ca}^{2+}, \mathrm{L}=55 \pm 20 \mathrm{~nm}\right.$, not shown) images are equivalent to those measured from XRD data. The indexed SAED patterns (insets) show the crystallographic planes of the hexagonal phase, i.e., (100), (110) in Figure 3a, or (100), (102), (200) in Figure 3c. The sample obtained for $x=0.01 \mathrm{Ca}^{2+}$ was studied in more details, as shown in Figure 3d-i. Figure $3 \mathrm{~d}$ displays the image in high angle annular dark field (HAADF) in Scanning Transmission Electron Microscopy (STEM). The elemental mappings composition of the nanoparticles (Figure 3 e,f,h,i) show a homogeneous distribution of Tb, Ca, P, and O. HRTEM images of this sample (Figure $3 \mathrm{~g}$ ) reveal lattice fringes, basically monodomains, whose d-spacing of $2.78 \AA$ corresponds to plane (102), also shown in the fast Fourier transform FFT images of this sample (Figure $3 \mathrm{~d}$, inset).

FTIR and Raman spectroscopy were employed to reveal the spectroscopic features of the $\mathrm{Ca}^{2+}$-doped samples (see Figure 4 for the stacking of spectra of precipitates prepared at different $\mathrm{Ca}^{2+}$ doping concentrations, and Supplementary Figures S1 and S2 for the stackings as a function of maturation time). 


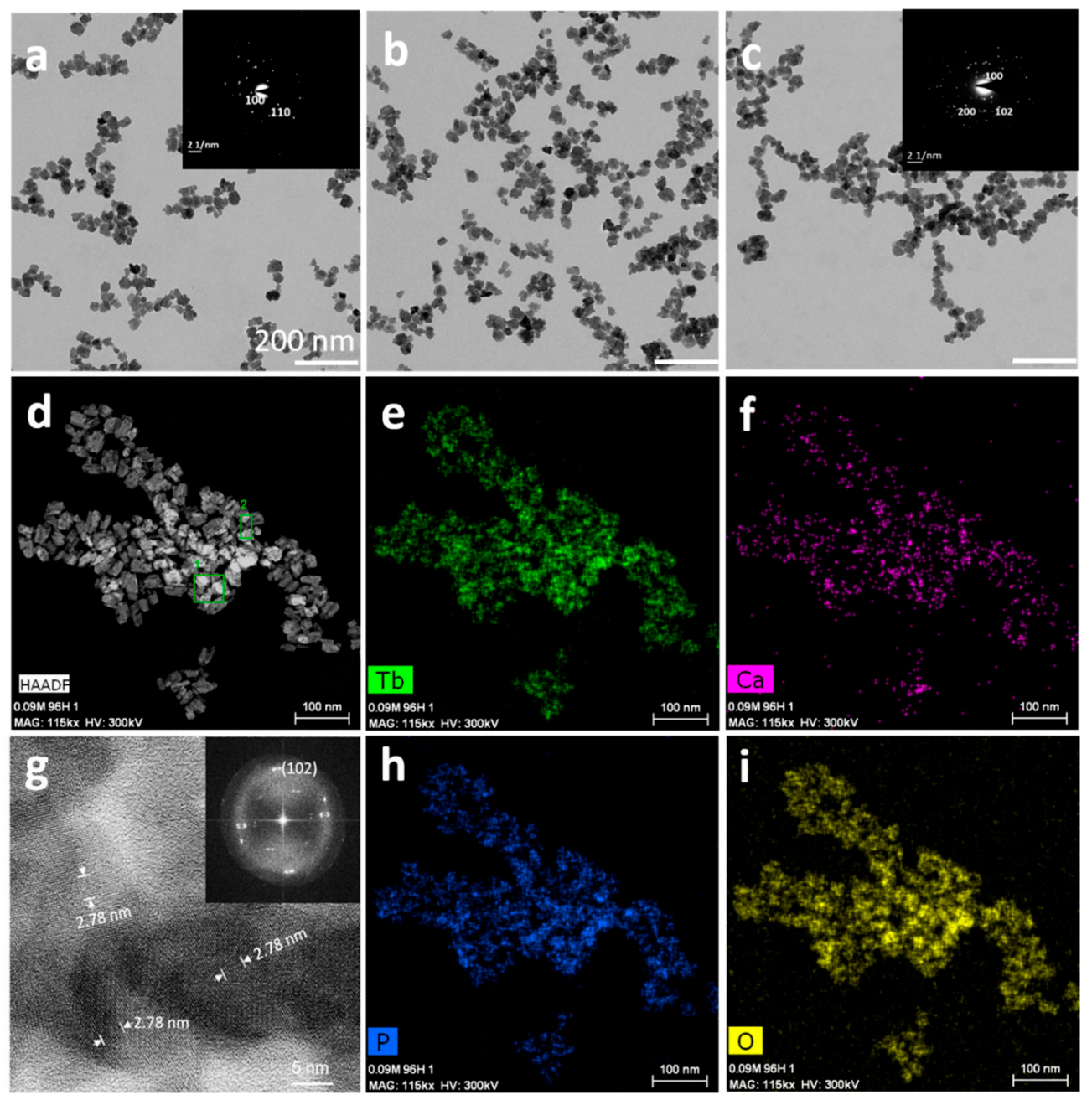

Figure 3. (a-c) TEM micrographs of cit-Ca ${ }^{2+}: \mathrm{TbPO}_{4} \cdot \mathrm{H}_{2} \mathrm{O}$ nanorods prepared with different $\mathrm{Ca}^{2+}$ doping concentrations at $96 \mathrm{~h}$ : (a) $x=0.01 \mathrm{M}$; (b) $x=0.03 \mathrm{M}$; (c) $x=0.05 \mathrm{M}$. Insets display SAED patterns of the nanoparticles. (d) HAADF-STEM micrograph of sample $x=0.01 \mathrm{M} \mathrm{Ca}^{2+}$. (e,f,h,i) EDX element mapping analysis of $\mathrm{Tb}, \mathrm{Ca}, \mathrm{P}$, and $\mathrm{O}$ in nanoparticles of image (d). (g) HR-TEM image showing lattice fringes and d-spacing of $2.78 \AA$ corresponding to plane (102) of nanocrystals of sample $x=0.01 \mathrm{M} \mathrm{Ca}^{2+}$. Inset in (g) shows the corresponding Fourier transform (FFT) image displaying the (102) plane.
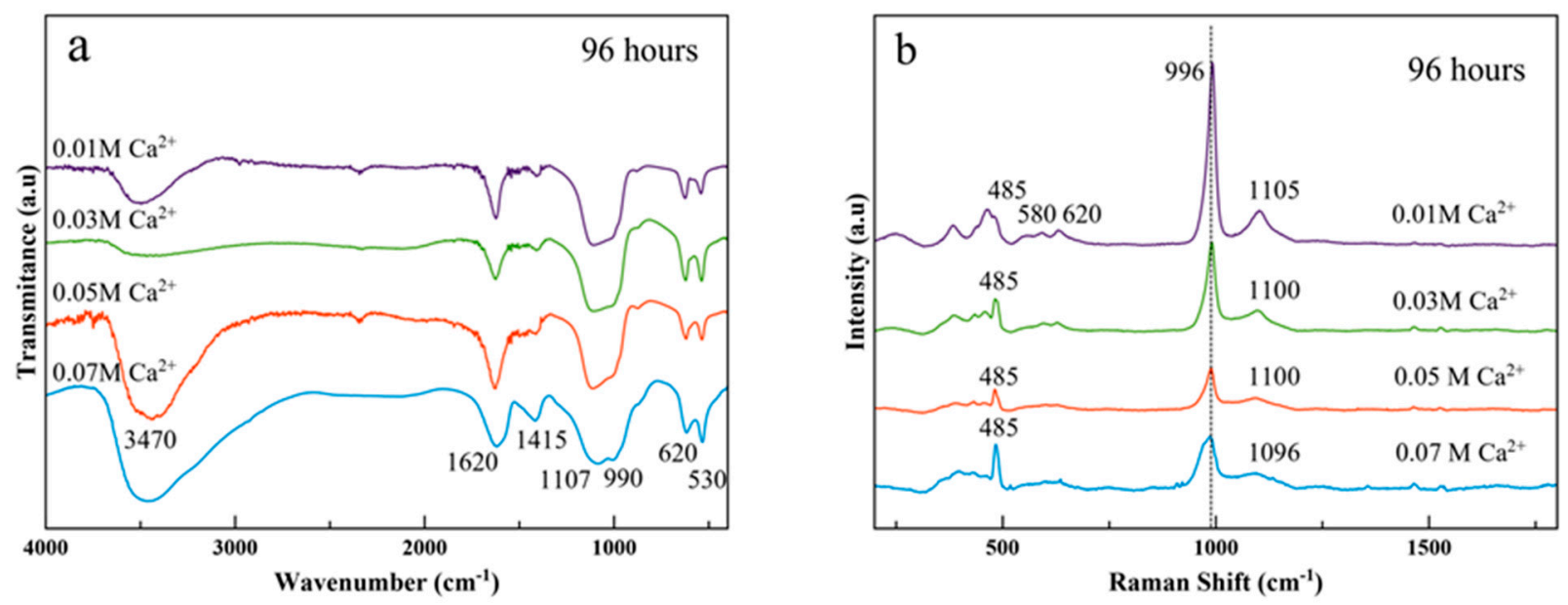

Figure 4. (a) FTIR and (b) Raman spectra of samples precipitated at $96 \mathrm{~h}$ using $\mathrm{Ca}^{2+}$-doping concentrations $x=0.01 \mathrm{M}$ (purple), $x=0.03 \mathrm{M}$ (green), $x=0.05 \mathrm{M}$ (red), $x=0.07 \mathrm{M}$ (light blue). 
FTIR spectra of $\mathrm{Ca}^{2+}$-doped samples (Figure 4a) show basically the same spectroscopic features upon calcium doping, especially for $x=0.01,0.03$, and $0.05 \mathrm{M} \mathrm{Ca}^{2+}$. These are a broadband between $3600-3700 \mathrm{~cm}^{-1}$ and $2600 \mathrm{~cm}^{-1}$ corresponding to the $\mathrm{O}-\mathrm{H}$ stretching of associated water, a main broad band at $1000-1100 \mathrm{~cm}^{-1}$, which corresponds to the antisymmetric stretching mode of $\mathrm{PO}_{4}{ }^{3-}$ groups $\left(v_{3} \mathrm{PO}_{4}\right)$ and two intense bands at $\sim 620$ and $535 \mathrm{~cm}^{-1}$ ascribed to the bending mode of the same $\mathrm{PO}_{4}{ }^{3-}$ groups $\left(v_{4} \mathrm{PO} 4\right)$. The broader signals around $1590-1620 \mathrm{~cm}^{-1}$ and $1405-1430 \mathrm{~cm}^{-1}$ are assignable to the antisymmetric and symmetric stretching frequencies of carboxylate $\left(-\mathrm{COO}^{-}\right)$groups of the adsorbed citrate [29]. No appreciable differences in peak assignments in the FTIR profiles were found after $4 \mathrm{~h}$ of maturation at any of the $\mathrm{Ca}^{2+}$ doping concentrations used (Supplementary Figure S1a-d).

In parallel, Raman characterization (Figure 4b) show the most intense band at $996 \mathrm{~cm}^{-1}$ $\left(v_{1}\right)$, which can be assigned to the $\mathrm{P}-\mathrm{O}$ symmetric stretching mode of $\mathrm{PO}_{4}$ group in raphdophane-type orthophosphates, while that at $\sim 1100 \mathrm{~cm}^{-1}$ is attributed to the antisymmetric stretching $\left(v_{3} \mathrm{PO}_{4}\right)$. The intensity of both bands decreases upon $\mathrm{Ca}^{2+}$ doping. The region comprised between 300 and $700 \mathrm{~cm}^{-1}$ corresponds to the deformation modes of the $\mathrm{PO}_{4}$ tetrahedron. The most intense band in this region is at $485 \mathrm{~cm}^{-1}$ and is assigned to the symmetric vibrations, while those at $\sim 570$ and $620 \mathrm{~cm}^{-1}$ can be ascribed to the asymmetric vibrations $\left(v_{4}\right)[38,39]$. The presence of vaterite in the spectra for $x=0.05$ and $0.07 \mathrm{M} \mathrm{Ca}^{2+}$, with bands at $1080-1090 \mathrm{~cm}^{-1} v_{1} \mathrm{CO}_{3}$ and $740-750 \mathrm{~cm}^{-1} v_{4} \mathrm{CO}_{3}$ [40] is hidden by the most intense bands of the phosphate groups. Clear differences were detected when plotting Raman spectra at increasing maturation times (Supplementary Figure S2). First, an increase in the intensity of the antisymmetric stretching mode $v_{3} \mathrm{PO}_{4}$ at $\sim 1100 \mathrm{~cm}^{-1}$, and particularly in the less $\mathrm{Ca}^{2+}$-doped sample (Supplementary Figure S2a) is observed. Second, the highest $\mathrm{Ca}^{2+}$-doped sample shows the $v_{1} \mathrm{PO}_{4}$ mode shifted from $970 \mathrm{~cm}^{-1}$ to $990 \mathrm{~cm}^{-1}$ (Supplementary Figure S2d), and the appearance of bands around $745 \mathrm{~cm}^{-1}$ and $1080 \mathrm{~cm}^{-1}$ (related to the vaterite phase). Also, the peaks at $845 \mathrm{~cm}^{-1}$ and $1460 \mathrm{~cm}^{-1}$ in samples at 4 and $24 \mathrm{~h}$, in vibrational zones of citrate groups [41].

Thermogravimetric analyses (Supplementary Figure S3) revealed a behavior very close to the ones reported for lanthanide phosphate materials of raphdophane structure $[29,42-45]$ but with some peculiarities reflecting the presence of citrates and carbonates in samples prepared at $x=0.05$ and $0.07 \mathrm{M} \mathrm{Ca}^{2+}$. The first weight loss, recorded between $\mathrm{T}_{\mathrm{amb}}$ and $120-140{ }^{\circ} \mathrm{C}$ of about $2 \mathrm{wt} \%$, is attributed to the residual adsorbed water, while the second one between $140{ }^{\circ} \mathrm{C}$ and about $600{ }^{\circ} \mathrm{C}$, of $5-5.5 \mathrm{wt} \%$, corresponds to the release of structural water, and this is the main weight loss. The third weight loss above $600{ }^{\circ} \mathrm{C}$ is associated with the decomposition of citrate molecules in samples prepared with $x=0.01$ and $0.03 \mathrm{M} \mathrm{Ca}^{2+}$, and with decomposition of citrate and of $\mathrm{CaCO}_{3}$ in $\mathrm{CO}_{2}$ and $\mathrm{CaO}$, when $x=0.05$ and $0.07 \mathrm{M} \mathrm{Ca}^{2+}$. Specific losses are observed in these two samples. For $x=0.05 \mathrm{M}$ $\mathrm{Ca}^{2+}$ the loss of $\mathrm{CO}_{2}$ is around $0.6 \mathrm{wt} \%$ and for $x=0.07 \mathrm{M} \mathrm{Ca}^{2+}$ is of $2.2 \mathrm{wt} \%$.

Quantitative analyses of $\mathrm{Ca}, \mathrm{P}, \mathrm{Tb}, \mathrm{C}$, and $\mathrm{H}$ of as-prepared samples are reported in Table 1. This table also shows the percent weights of structural $\mathrm{H}_{2} \mathrm{O}$ determined by TGA and thus, the hydration number (n) of the raphdophane phase. Percent weights of $\mathrm{CaCO}_{3}$ and citrate were determined by combining TGA data with mass balances. The data reveal increased percentages of dopant Ca from $0.42 \mathrm{wt} \%$ to $8.11 \mathrm{wt} \%$ in the structure of $\mathrm{TbPO}_{4} \cdot \mathrm{nH}_{2} \mathrm{O}$ as the percentage of $\mathrm{Tb}$ decreases, according to the increase of $\mathrm{Ca}^{2+} / \mathrm{Tb}^{3+}$ ratio in the precursor solutions.

In these samples, the percentages of adsorbed citrate were around $1.1-1.2 \mathrm{wt} \%$ but in the highest $\mathrm{Ca}^{2+}$-doped sample that percentage rose to $4 \mathrm{wt} \%$. This higher amount of citrate is likely due to the higher percentage of $\mathrm{CaCO}_{3}$, which can be also coated with citrate. Table 1 also shows that structural $\mathrm{H}_{2} \mathrm{O}$ ranges between 5.0 and $6.3 \mathrm{wt} \%$ rendering hydration numbers around 0.9 . 
Table 1. Quantitative analyses of $\mathrm{Ca}, \mathrm{P}, \mathrm{Tb}, \mathrm{C}, \mathrm{H}$, and estimated percent weights of structural citrate, $\mathrm{H}_{2} \mathrm{O}, \mathrm{CaCO}_{3}$ and hydration number $\mathrm{n}$ of the samples prepared with $\mathrm{Ca}^{2+}$ doping concentration $\mathrm{x}$ ranging from 0.01 to $0.07 \mathrm{M}$, at $96 \mathrm{~h}$.

\begin{tabular}{|c|c|c|c|c|c|c|c|c|c|}
\hline $\begin{array}{c}x\left[\mathrm{Ca}^{2+}\right] \\
\mathrm{mol} / \mathrm{L}\end{array}$ & $\mathrm{Ca}(w \mathrm{t} \%)$ & $\begin{array}{c}P \\
(w t \%)\end{array}$ & $\begin{array}{c}\mathrm{Tb} \\
(\mathbf{w t} \%)\end{array}$ & $\underset{(w t \%)}{C}$ & $\begin{array}{c}\mathrm{H} \\
(w \mathrm{t} \%)\end{array}$ & $\begin{array}{c}\text { Cit } \\
(w t \%)\end{array}$ & $\begin{array}{c}\mathrm{H}_{2} \mathrm{O} \text { str } \\
(\mathrm{wt} \%)\end{array}$ & $\begin{array}{l}\mathrm{CaCO}_{3} \\
(\mathrm{wt} \%)\end{array}$ & $\mathbf{n}$ \\
\hline 0.01 & 0.42 & 10.5 & 61.4 & 0.46 & 0.72 & 1.21 & 5.0 & 0 & 0.88 \\
\hline 0.03 & 2.91 & 10.9 & 39.8 & 0.42 & 0.74 & 1.10 & 5.44 & 0.2 & 0.86 \\
\hline 0.05 & $6.76,6.09 *$ & 12.0 & 27.5 & 0.52 & 0.75 & 1.12 & 6.68 & 0.76 & 0.93 \\
\hline 0.07 & $10.32,8.11$ * & 11.45 & 16.9 & 1.72 & 1.04 & 3.96 & 6.33 & 1.75 & 0.95 \\
\hline
\end{tabular}

The analysis of CSD and $\zeta$-potential versus $\mathrm{pH}$ of aqueous suspensions of the nanoparticles is also relevant to assess their potential as luminescent probes in nanomedicine applications. The tendency of the colloid to disperse or aggregate in simulated physiological conditions in the blood ( $\mathrm{pH}$ around 7.4) or in the tumor microenvironment ( $\mathrm{pH}$ around 5-6) are related to the size and surface charge of the nanoparticles [16,46]. In addition, these features have an impact on the formation of the protein corona around the nanoparticles [47]. In this study, the CSD of cit- $\mathrm{Ca}^{2+}: \mathrm{TbPO}_{4} \cdot \mathrm{nH}_{2} \mathrm{O}$ nanoparticles was plotted as cumulative volume-based distribution because they visually show the percentiles of the distribution $\mathrm{D}_{10}, \mathrm{D}_{50}$ and $\mathrm{D}_{90}$ (Figure 5 and Supplementary Figure S4), widely employed to characterize crystal populations in pharmaceutical industry. These percentiles characterize the percentage of cumulative volume undersize distribution (percentage of the population smaller than the indicated size). Thus, $\mathrm{D}_{10}$ is a percentile closer to the size of the individual particles while $D_{50}$, the median of the population, is here somewhat influenced by particle aggregation. $D_{90}$ is entirely influenced by the aggregation of nanocrystals. The percentiles for samples prepared with $\mathrm{x}=0.01,0.03,0.05$, and $0.07 \mathrm{M} \mathrm{Ca}^{2+}$ for $96 \mathrm{~h}$ were $\mathrm{D}_{10} 21,51,57$, and $45 \mathrm{~nm}$, respectively, and $\mathrm{D}_{50} 37,531,122$, and $94 \mathrm{~nm}$, respectively (Figure 5b).

In these samples, the evolution of cumulative CSD versus time (at $4 \mathrm{~h}, 24 \mathrm{~h}$ and $96 \mathrm{~h}$, Figure S4a-d) does not follow a general trend, thus reflecting a difference in Ca composition as well as the presence of a secondary phase (vaterite) at high doping concentrations and its influence in the aggregation.

These differences are also reflected in the profile of the $\zeta$-potential versus $\mathrm{pH}$ curves (Figure $5 \mathrm{c}-\mathrm{f}$ ). While samples obtained with $x=0.01$ and $0.03 \mathrm{M} \mathrm{Ca}^{2+}$ displayed similar curves, with $\zeta$-potential values -17.3 and $-17.4 \mathrm{mV}$ at $\mathrm{pH} 7$, and -14.0 and $-10.5 \mathrm{mV}$ at pH 5 (Figure $5 \mathrm{c}, \mathrm{d}$ ), the curves of sample obtained with $x=0.05 \mathrm{M} \mathrm{Ca}^{2+}$ (Figure 5e) and $x=0.07 \mathrm{M} \mathrm{Ca}^{2+}$ (Figure 5f) show a different profile. The minimum $\zeta$-potential values were found at $\mathrm{pH} 6.0(-11.5 \mathrm{mV})$ and $\mathrm{pH} 8.0(-15.9 \mathrm{mV})$ respectively. $\zeta$-potentials were 0 beyond $\mathrm{pH} 6.0$ in the first case, and below $\mathrm{pH} 8.0$ in the second one.

\subsection{Luminescence Properties of $\mathrm{Cit}-\mathrm{Ca}^{2+}: \mathrm{TbPO}_{4} \cdot n \mathrm{H}_{2} \mathrm{O}$ Nanoparticles}

\subsubsection{Luminescence in Solid-State}

It is well-known that some lanthanides, especially europium (III) and terbium (III), form highly fluorescent chelates with many different organic ligands. The sensitized fluorescence results from the ligand absorbing light, the energy of which is then transferred to the chelated metal ion. In fact, $\mathrm{Tb}(\mathrm{III})$ emits the energy as narrow-banded, line-type fluorescence with a long Stokes shift (over $250 \mathrm{~nm}$ ) and an exceptionally long fluorescence decay time (up to $1 \mathrm{~ms}$ ) [48]. Because of the long fluorescence decay time (over 10 times longer than the average background fluorescence) of $\mathrm{Tb}(\mathrm{III})$, a delay time $\left(\mathrm{t}_{\mathrm{d}}\right)$ and a gate time $\left(\mathrm{t}_{\mathrm{g}}\right)$ can be used during the measuring, remarkably reducing the background fluorescence. 

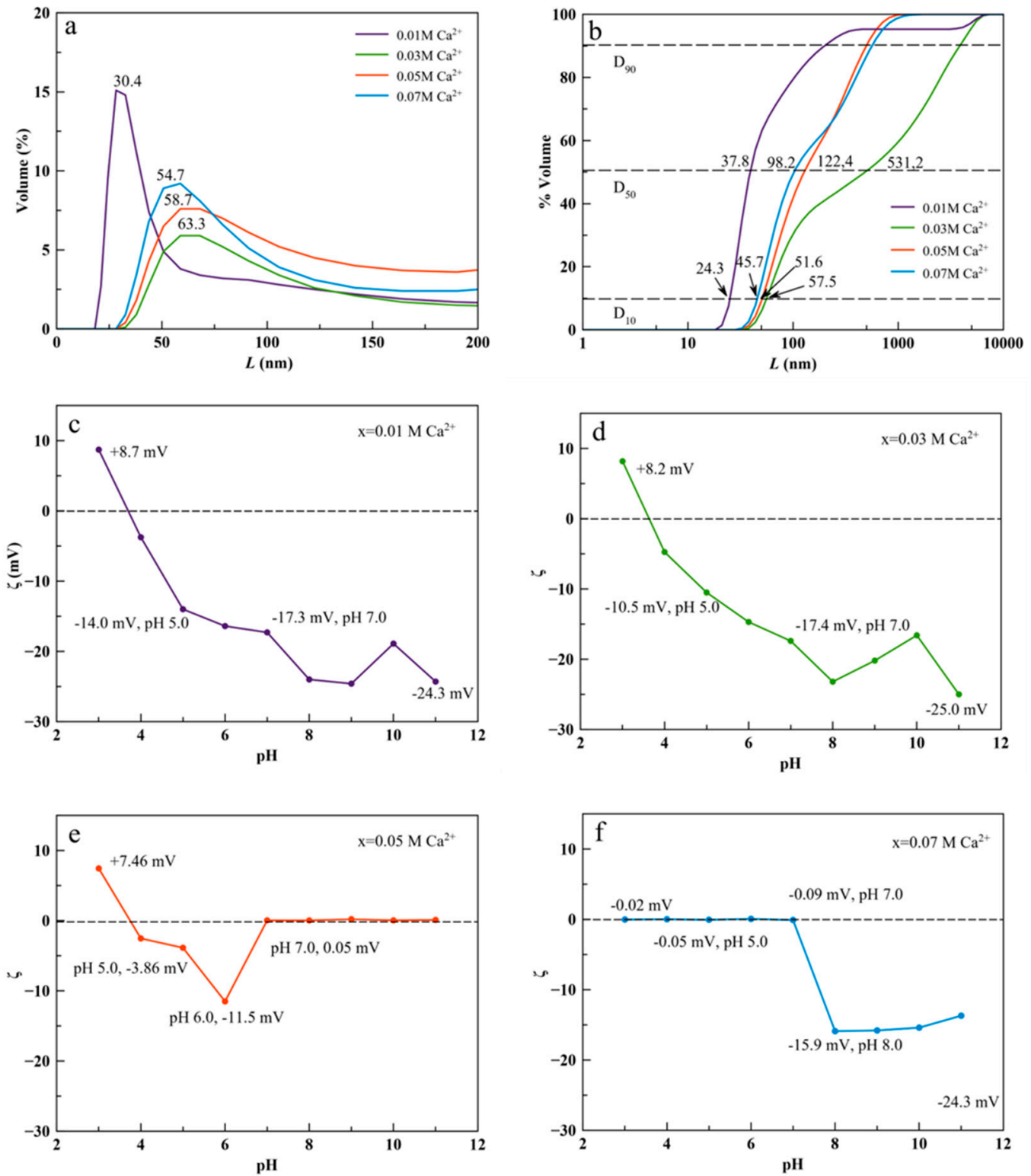

Figure 5. (a) Volume-based CSD and (b) cumulative volume-based CSD of cit-Ca ${ }^{2+}: \mathrm{TbPO}_{4} \cdot \mathrm{nH}_{2} \mathrm{O}$ nanocrystals prepared with $\mathrm{Ca}^{2+}$ doping concentrations $x=0.01$ (purple), 0.03 (green), 0.05 (red) and $0.07 \mathrm{M}$ (light blue) for $96 \mathrm{~h}$, measured in aqueous suspensions (pHs 8.4, 8.9, 8.3, and 7.80, respectively). (c-f) $\zeta$-potential versus $\mathrm{pH}$ of aqueous suspensions of cit-Ca ${ }^{2+}: \mathrm{TbPO}_{4} \cdot \mathrm{nH}_{2} \mathrm{O}$ nanocrystals.

The luminescence properties of solid cit- $\mathrm{Ca}^{2+}: \mathrm{TbPO}_{4} \cdot \mathrm{nH}_{2} \mathrm{O}$ samples are shown in Supplementary Materials (Figures S5 and S6). They are the same as those depicted in Figure 6 which correspond to $x=0.01 \mathrm{M} \mathrm{Ca}^{2+}$; neither the maturation time nor the $\mathrm{Ca}^{2+}$ doping concentrations affect the excitation and emission wavelengths. This finding is expected because the electronic transitions of $f$ orbitals are not affected by crystal's field.

The observed excitation wavelengths for the powder were 230, 284, 300, 320, 340, 350, 368 and $375 \mathrm{~nm}$. The broad bands between 200 and $300 \mathrm{~nm}$, centered at $230 \mathrm{~nm}$, correspond to charge transfer (called charge transfer band, CTB), which occurs by electron delocalization from the filled $2 \mathrm{p}$ shell of $\mathrm{O}^{2-}$ to the partially filled $4 \mathrm{f}$ shell of $\mathrm{Tb}^{3+}$. Also, this band can partially be attributed to the charge transfer transition $\mathrm{X}^{5+}-\mathrm{O}^{2-}[49,50]$. The rest of the less intensive excitation wavelengths correspond to the ${ }^{7} \mathrm{~F}_{6} \rightarrow{ }^{5} \mathrm{I}_{8}$ and ${ }^{5} \mathrm{~F}_{4,5} \rightarrow{ }^{5} \mathrm{H}_{4}$, ${ }^{7} \mathrm{~F}_{6} \rightarrow{ }^{5} \mathrm{H}_{5,6},{ }^{7} \mathrm{~F}_{6} \rightarrow{ }^{5} \mathrm{H}_{7},{ }^{7} \mathrm{~F}_{6} \rightarrow{ }^{5} \mathrm{~L}_{7,8}$ and ${ }^{7} \mathrm{~F}_{6} \rightarrow{ }^{5} \mathrm{~L}_{7,8},{ }^{7} \mathrm{~F}_{6} \rightarrow{ }^{5} \mathrm{~L}_{9},{ }^{5} \mathrm{D}_{2},{ }^{5} \mathrm{G}_{5},{ }^{7} \mathrm{~F}_{6} \rightarrow{ }^{5} \mathrm{~L}_{10}$, and ${ }^{7} \mathrm{~F}_{6}$ $\rightarrow{ }^{5} \mathrm{G}_{6},{ }^{5} \mathrm{D}_{3}$ transitions [51]. 


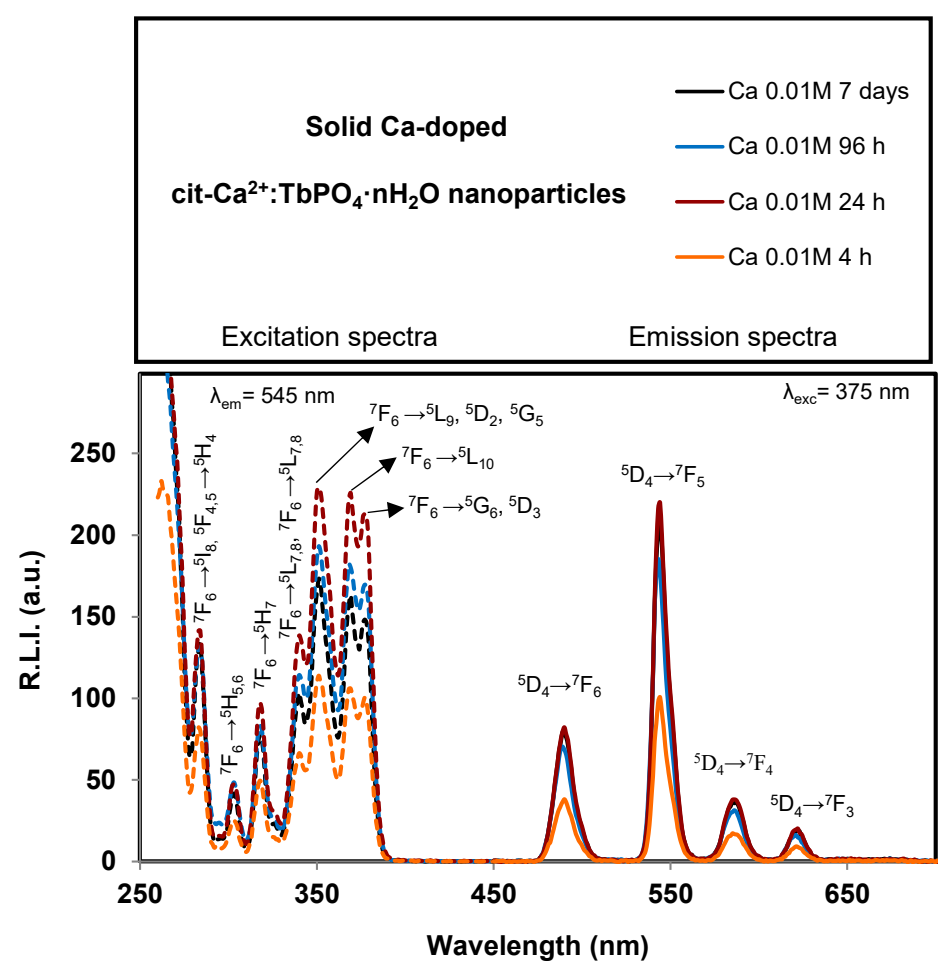

Figure 6. Excitation (dashed lines) and emission (solid lines) uncorrected spectra of solid cit$\mathrm{Ca}^{2+}: \mathrm{TbPO}_{4} \cdot \mathrm{nH}_{2} \mathrm{O}$ samples prepared with $x=0.01 \mathrm{M} \mathrm{Ca}^{2+}$ at maturation times of $4 \mathrm{~h}, 24 \mathrm{~h}, 96 \mathrm{~h}$ and 7 days.

$\mathrm{SM}$ (see Supplementary Figure S5) shows the emission spectra of the cit- $\mathrm{Ca}^{2+}: \mathrm{TbPO}_{4} \cdot \mathrm{nH}_{2} \mathrm{O}$ with $x=0.01 \mathrm{M}$ and $96 \mathrm{~h}$ of maturation time using 230 and $375 \mathrm{~nm}$ excitation wavelengths. It is possible to conclude that the emission spectra are the same; only the emission intensity is affected. In order to increase the biological applicability of the system, $375 \mathrm{~nm}$ (which is closer to the visible range) was selected as excitation wavelength.

Concerning the emission wavelengths, they are centered at 490, 545, 586 and $620 \mathrm{~nm}$ which correspond to the $\mathrm{Tb}^{3+}{ }^{5} \mathrm{D}_{4} \rightarrow{ }^{7} \mathrm{~F}_{6},{ }^{5} \mathrm{D}_{4} \rightarrow{ }^{7} \mathrm{~F}_{5},{ }^{5} \mathrm{D}_{4} \rightarrow{ }^{7} \mathrm{~F}_{4}$ and ${ }^{5} \mathrm{D}_{4} \rightarrow{ }^{7} \mathrm{~F}_{3}$ transitions, respectively [52]. The emission wavelength corresponding to the hypersensitive transition without inversion centre $\left({ }^{5} \mathrm{D}_{4} \rightarrow{ }^{7} \mathrm{~F}_{5}, 545 \mathrm{~nm}\right.$ for $\left.\mathrm{Tb}^{3+}\right)$ produces the highest relative luminescence intensity (R.L.I.). Therefore, the optimum excitation and emission wavelengths of solid cit-Ca ${ }^{2+}: \mathrm{TbPO}_{4} \cdot \mathrm{nH}_{2} \mathrm{O}$ samples were $375 \mathrm{~nm}$ and $545 \mathrm{~nm}$, respectively.

Supplementary Figures S7 and S8 show the effect of maturation time $(t)$ at different doping $\mathrm{Ca}^{2+}$ concentrations $(x)$ on the relative luminescence intensity (R.L.I.).

The R.L.I. of samples prepared with $x=0.01,0.03$ and $0.05 \mathrm{M} \mathrm{Ca}^{2+}$ is not affected by the maturation time (Supplementary Figure S7). It can be due to the slowing down of the crystal growth caused by the adsorption of citrate up to $2 \mathrm{~h}$ maturation [29]. In contrast, for $x=0.07 \mathrm{M} \mathrm{Ca}^{2+}$ doping concentration, the R.L.I is highly affected; at shorter times ( 4 and $24 \mathrm{~h}$ ) the signal is high, but it decreases drastically in the sample prepared at $96 \mathrm{~h}$. As it was previously commented for this concentration, at shorter times (4 and $24 \mathrm{~h}$ ) the material is amorphous without an ordered structure and with a high amount of $\mathrm{Tb}^{3+}$ adsorbed on its surface, showing high luminescence. However, at $96 \mathrm{~h}$ it is crystalline, exhibiting an improved internal ordering in which $\mathrm{Tb}^{3+}$ is buried in the structure of the nanoparticles, resulting in a decrease on the luminescence. It was previously reported that amorphous materials provide much more luminescence emission than crystalline ones [29]. On the other hand, this sample contains a higher proportion of citrate $(\sim 4 \mathrm{wt} \%)$ providing a less emissive material than at other $\mathrm{Ca}^{2+}$-doped concentrations.

Analyzing the variation of the R.L.I at a fixed maturation time versus $x$ it is also possible to observe that the main differences are found for $x=0.07 \mathrm{M}$ (Supplementary 
Figure S8). It can be explained for the same reasons commented before that, at shorter maturation times, the sample has an amorphous nature and at the higher one it is crystalline, and the amount of citrate is higher, providing a less luminescent material.

Concerning the luminescence lifetime $(\tau)$, Supplementary Figures S9-S11 show the luminescence decay curves and the variation of the luminescence lifetime versus both maturation time and $\mathrm{Ca}^{2+}$ doped concentrations, respectively. For each case, the decay profile was analyzed as a single exponential component (R.L.I. $\left.=A \cdot e^{\wedge}(-t / \tau)+C\right)$. It is possible to conclude that the maturation time at a given $\mathrm{Ca}^{2+}$ doped concentration does not affect the lifetime (Supplementary Figure S10). However, the luminesce lifetime for a given maturation time is increased by increasing the $x$. It might be due to the presence of progressive amounts of vaterite.

\subsubsection{Luminescence of the Nanoparticles in Aqueous Suspension}

The luminescence properties of cit- $\mathrm{Ca}^{2+}: \mathrm{TbPO}_{4} \cdot \mathrm{nH}_{2} \mathrm{O}$ dispersed in aqueous media are similar to those depicted in Figure 7, which corresponds to $x=0.01 \mathrm{M} \mathrm{Ca}^{2+}, 96 \mathrm{~h}$

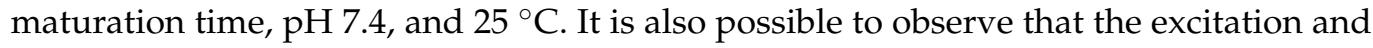
emission wavelength of the material dispersed in water is practically the same than those in powder as well as the luminescence lifetime is not affected by dispersing the sample in an aqueous media. On the other hand, it is possible to conclude that the material has the same luminescence properties (R.L.I. and lifetime) at any physiological $\mathrm{pH}$, so variation of the $\mathrm{pH}$ in real biological samples does not affect the luminescence properties of the particles.

The effect of ionic strength was evaluated by suspending the particles in $0,25,50,75$ and $100 \mathrm{mM} \mathrm{NaCl}$ solutions (Figure S12). It is possible to deduce that neither the R.L.I. nor the luminescence lifetime is significantly affected by the ionic strength, which is also important for the final applications of these nanoparticles.

The temperature may also theoretically affect the luminescence by quenching of the excited states, i.e., for increasing $\mathrm{T}$ the molecular motion and collisions increase, and hence the luminescence emission decreases by increasing encounters probabilities. [53] Figure S13 shows the experimental results. To sum up, increasing from 25 to $40{ }^{\circ} \mathrm{C}$ does not affect considerably the luminescence emission of all the tested materials in suspension. The change in fluorescence intensity is normally $1 \%$ per degree Celsius [53] and the decreases for these materials were $0.2,0.4,2.6$, and $0.6 \%$ per degree Celsius, for $0.01 \mathrm{M}, 0.03 \mathrm{M}$, $0.05 \mathrm{M}$ and $0.07 \mathrm{M} \mathrm{Ca}^{2+}$ doping concentration, respectively. This is very important in view of medical and biomedical imaging $\left(\sim 37.4^{\circ} \mathrm{C}\right)$ while the rest of the experiments were performed at room temperature $\left(25^{\circ} \mathrm{C}\right)$.

\subsection{Cytocompatibility of $\mathrm{Cit}-\mathrm{Ca}^{2+}: \mathrm{TbPO}_{4} \cdot n \mathrm{H}_{2} \mathrm{O}$ Nanoparticles}

The cytocompatibility of cit- $\mathrm{TbPO}_{4} \cdot \mathrm{nH}_{2} \mathrm{O}$ samples doped with different concentrations of $\mathrm{Ca}^{2+}$ was tested in a MTT assay on the GTL-16 human carcinoma cells and the A549 human lung adenocarcinoma cells, after incubation at concentrations ranging from 0.1 to $100 \mu \mathrm{g} / \mathrm{mL}$. GTL-16 cells were chosen because this is the reference standard cell line used in the lab for this type of experiments. In particular, the fact that these tumor cells express a high level of receptors for a growth factor has made this cell line a good model for studying tumor cell ligand-mediated targeting by nanoparticles, possibly loaded by a drug $[6,16]$. A549 cells were chosen since they are easily available cells in many laboratories.

No toxicity was observed on both cell lines at any nanoparticle concentration (Figure 8), since in all cases a cell viability higher than $85 \%$ was observed, largely above the cut-off of 70\% indicated by ISO 10993-5:2009 [54]. The presence of the doping $\mathrm{Ca}^{2+}$ appears to increase the biocompatibility of the nanocrystals in a dose-dependent manner. On the other side, both cell types were sensitive to the toxic activity of hydrogen peroxide, which reduced their viability to less than $50 \%$. This in vitro assay thus shows the good cytocompatibility of the cit-Ca ${ }^{2+}: \mathrm{TbPO}_{4} \cdot \mathrm{nH}_{2} \mathrm{O}$ nanoparticles. 

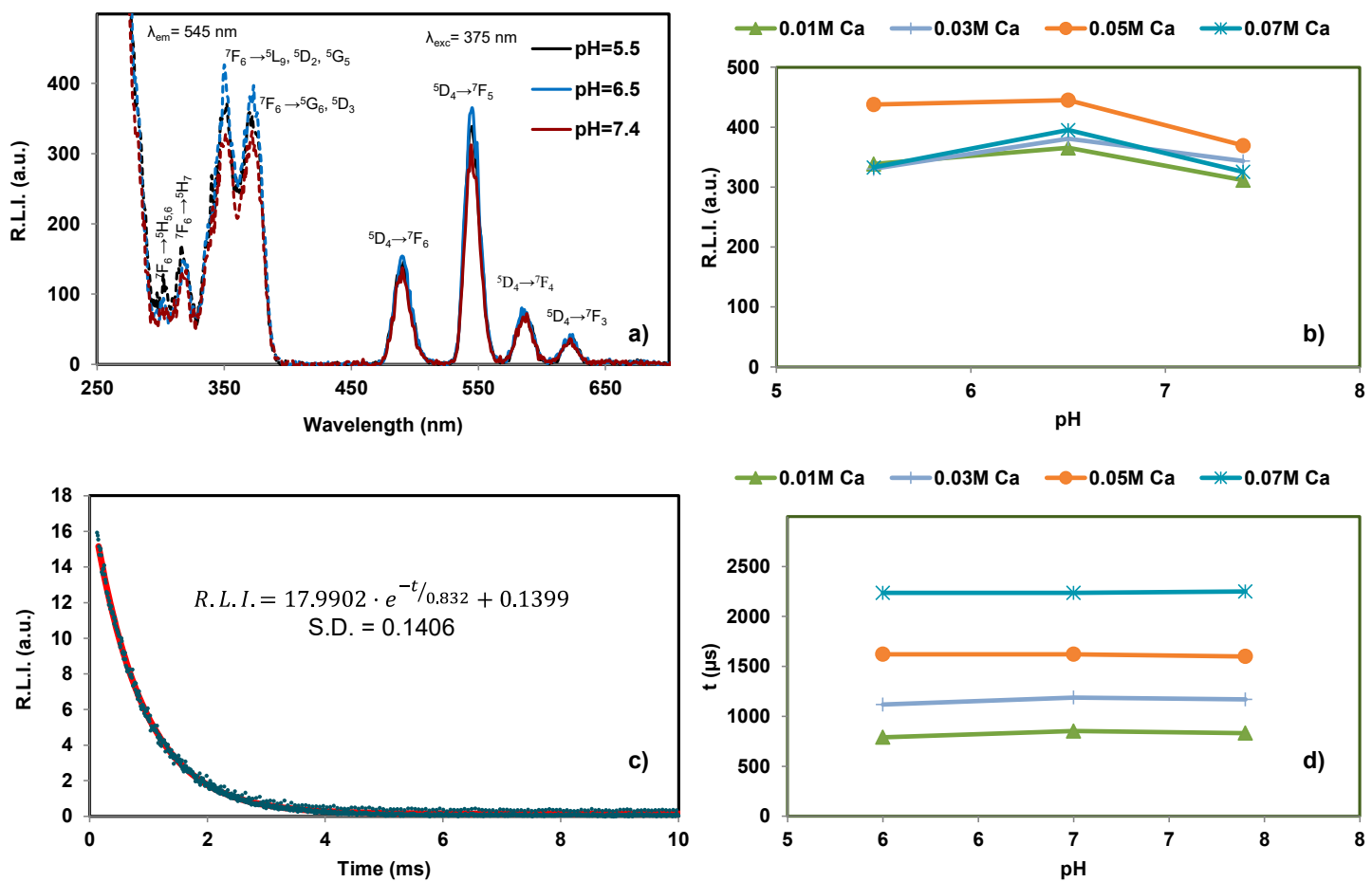

Figure 7. Luminescence properties of cit- $\mathrm{Ca}^{2+}: \mathrm{TbPO}_{4} \cdot \mathrm{nH}_{2} \mathrm{O}$ dispersed in aqueous media with $x=0.01 \mathrm{M} \mathrm{Ca}^{2+}, 96 \mathrm{~h}$ maturation time and $25^{\circ} \mathrm{C}$ versus $\mathrm{pH}$; (a) Excitation (dashed line) and emission (solid line) spectra; (b) Variation of R.L.I. versus $\mathrm{pH}$; (c) Luminescence decay curve; and (d) Variation of luminescence lifetime with the $\mathrm{pH}$.
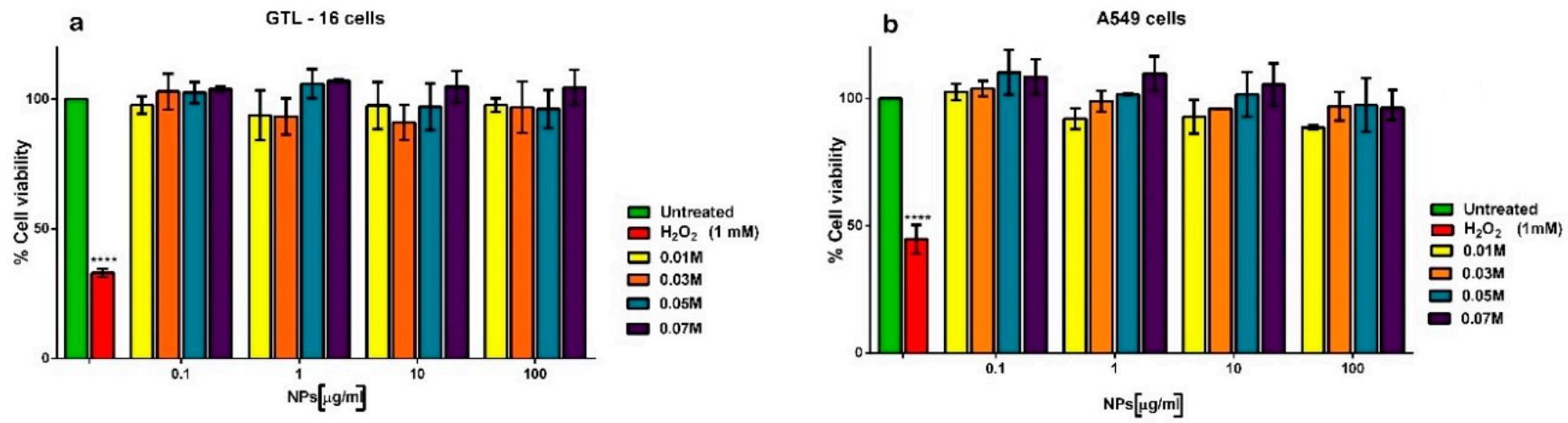

Figure 8. Viability of GTL-16 cells (a) and of A549 cells (b) incubated with cit-Ca ${ }^{2+}: \mathrm{TbPO}_{4} \cdot \mathrm{nH}_{2} \mathrm{O}$ particles prepared with different $\mathrm{Ca}^{2+}$-doping concentration for three days. Viability was assessed in MTT assays. Data represent means \pm SD of three independent experiments performed in triplicate and statistical analyses were carried on using One-way ANOVA, with Bonferroni comparison test. For statistical analysis all data were compared to untreated samples and only samples treated with $\mathrm{H}_{2} \mathrm{O}_{2}$ displayed statistically significant difference (**** $\left.p=0.0005\right)$.

\section{Discussion}

The above results confirm the herein reported bioinspired crystallization route succeeded in preparing cit- $\mathrm{Ca}^{2+}: \mathrm{TbPO}_{4} \cdot \mathrm{nH}_{2} \mathrm{O}$ nanocrystals of the hexagonal rhabdophane phase, with $\mathrm{n} \sim 0.9$ and tailored $\mathrm{Ca}^{2+}$ content between $0.42 \mathrm{wt} \%$ and $8.11 \mathrm{wt} \%$. The nanocrystals displayed isometric ill-defined morphologies, and adsorbed citrate on their surfaces, a chemical feature exhibited by bone nAps [34]. As $\mathrm{Ca}^{2+}$ increases the risk of appearance of a secondary phase of $\mathrm{CaCO}_{3}$ (vaterite) must be considered. However, this trouble can be properly assumed since vaterite is biocompatible. In addition, the percent weight of citrate increases, particularly in the sample prepared with $x=0.07 \mathrm{M}$. As citrate molecules were not removed after different cycles of washing, they should be adsorbed not only to $\mathrm{Ca}^{2+}: \mathrm{TbPO}_{4} \cdot \mathrm{H}_{2} \mathrm{O}$ but also to the $\mathrm{CaCO}_{3}$ surface. As hypothesized, these features have an 
impact on the cytocompatibility of the cit- $\mathrm{Ca}^{2+}: \mathrm{TbPO}_{4} \cdot \mathrm{H}_{2} \mathrm{O}$. In fact, all samples displayed a high cytocompatibility when tested on two human carcinoma cell lines and cell viability appears to positively correlate with the amount of doping $\mathrm{Ca}^{2+}$ in the nanocrystals, in line with what was reported for cit- $\mathrm{Ca}^{2+}: \mathrm{EuPO}_{4} \cdot \mathrm{nH}_{2} \mathrm{O}$ nanocrystals [29].

Also important are the average sizes of the nanocrystals. The average sizes measured in TEM or SEM micrographs were equivalent to those of their crystal domains, indicating they are basically monodomains, with no appreciable dependence of their morphology (isometric) with $\mathrm{Ca}^{2+}$ doping. This finding contrasts with what was reported for cit$\mathrm{Ca}^{2+}: \mathrm{EuPO}_{4} \cdot \mathrm{H}_{2} \mathrm{O}$ nanoparticles [29]. Those nanoparticles showed elongated (anisometric) morphologies and their aspect ratio decreased with $\mathrm{Ca}^{2+}$ doping. It is worth highlighting that percentiles $\mathrm{D}_{10}$ of the CSD are close to these average sizes deduced from electron microscopy images. This finding indicates that aggregation is very low and $\mathrm{D}_{10}$ could define the nanoparticle size in the context of the whole population, particularly in the less $\mathrm{Ca}^{2+}$ doped sample. $\mathrm{D}_{50}$, instead, doubles the $\mathrm{D}_{10}$ percentile or is even 10 times higher in sample $x=0.03 \mathrm{M} \mathrm{Ca}^{2+}$, suggesting a higher contribution of particle aggregation below the median size.

Concerning the $\zeta$-potential versus $\mathrm{pH}$ of nanoparticle suspensions, those samples prepared at $x=0.01$ and $0.03 \mathrm{M} \mathrm{Ca}^{2+}$ show a high and negative $\zeta$-potential above $\mathrm{pH} 4$, therefore they display great stability both at $\mathrm{pH} \sim 7.4$ simulating physiological $\mathrm{pH}$, and at pHs $5-6$, simulating the environment of cancer cells. The CSD of the sample prepared at $x=0.01 \mathrm{M} \mathrm{Ca}^{2+}$ correlates well with the $\zeta$-potential versus $\mathrm{pH}$ measurements of this sample, and reflects the role of surface charge on the stability of the nanoparticles and their aggregation behavior. However, there is a lack of correlation between the CSD and the $\zeta$-potential values for the $0.03 \mathrm{M} \mathrm{Ca}^{2+}$ sample, indicating that other effects besides the nanoparticles surface charge can be involved in particle aggregation. Also, the other samples present a negative $\zeta$-potential, but these are less negative, indicating poorer stability of the suspensions at the $\mathrm{pHs}$ of interest for biological applications. In the latter samples, the curves reflect the presence of vaterite, and also the increasing amount of citrate, which correlate with a relatively higher cytocompatibility. Thus, when $x=0.05 \mathrm{M}$ $\mathrm{Ca}^{2+}$ the $\zeta$-potential value close to zero indicates a high amount of surface $\mathrm{Ca}^{2+}$ that compensate the negative charge due to citrate at basic $\mathrm{pH}$. When $x=0.07 \mathrm{M} \mathrm{Ca}^{2+}$ (Figure 5f) the $\zeta$-potential values at basic $\mathrm{pHs}$ are again negative. This finding is due to the higher percentage of citrate negatively charged respect to positively charged surface $\mathrm{Ca}^{2+}$ coating both $\mathrm{Ca}^{2+}: \mathrm{TbPO}_{4} \cdot \mathrm{nH}_{2} \mathrm{O}$ and $\mathrm{CaCO}_{3}$ particles. It was reported that the mode of adsorption of citrate on a substrate depends on the $\mathrm{pH}$ of the solution. Citrate molecules absorb on monodentate or bidentate configuration (i.e., on nanoapatites [55]) displaying the third carboxylate group upward toward the solution. This arrangement gives rise to a negative net surface charge that is reflected in a negative $\zeta$-potential. While preventing aggregation, the negative $\zeta$-potentials of nanocrystal could interfere with their interaction with the cell surface, which is also negatively charged, and their eventual uptake by cell endocytosis. This behavior, however, is not the only possibility, since some negatively charged nanoparticles, such as Fluorescein-5-isothiocyanate-labelled hydroxypatite nanoparticles [6] and magnetic nanoparticles [56], were reported to be internalized by cells.

To discuss how the nanocrystals herein described were formed, one must consider both the influence of their tridimensional crystal structure and the presence of additives in the precursor solution. Indeed, the growth morphology of a nanocrystal results from the interplay between the growth rates of its outermost crystallographic planes and the growth-inhibiting/promoting effect of the additives. The raphdophane structure of the $\mathrm{LnPO}_{4} \cdot \mathrm{nH}_{2} \mathrm{O}$ is described as chains formed by lanthanide with eight-fold coordination alternating with tetrahedral orthophosphate ions. These chains are extended along with the c-axis, each one linked to four neighboring chains, thus forming open channels which are filled with between 0.5 to $2 \mathrm{H}_{2} \mathrm{O}$ molecules per formula unit, stabilizing the structure $[15,20,57]$. Consequently, $\mathrm{LnPO}_{4} \cdot \mathrm{nH}_{2} \mathrm{O}$ show the general trend to grow along [001] direction forming nanowires. 
The second influence we must consider is the effect of citrate, which is a known growth inhibitor. Citrate adsorbs on specific outermost planes of incipiently formed nanocrystals slowing down its growth along the [001] direction, and leading to the formation of nanocrystals with lower aspect ratios than those formed in additive-free solutions. As we obtain basically the same crystal morphology irrespective of the amount of $\mathrm{Ca}^{2+}$ doping the cit- $\mathrm{Ca}+: \mathrm{TbPO}_{4} \cdot \mathrm{nH}_{2} \mathrm{O}$ structure, we conclude that $\mathrm{Ca}^{2+}$ has limited inhibiting/promoting effect on the growth of these nanocrystals, against that of citrate, in contrast to what found in cit- $\mathrm{Ca}^{2+}: \mathrm{EuPO}_{4} \cdot \mathrm{nH}_{2} \mathrm{O}$ [29]. On the other side, as already discussed above, the addition of this metal ion had a positive effect on the cytocompatibility of the nanoparticles, in line with the previous report relative to cit- $\mathrm{Ca}^{2+}: \mathrm{EuPO}_{4} \cdot \mathrm{nH}_{2} \mathrm{O}$ [29]. Moreover, at the highest doping dose, $\mathrm{Ca}^{2+}$ enhances the adsorption of citrate, an ion contributing to biomimetic properties of apatites [34].

Finally, the luminescence study of these nanoparticles in solid phase indicate that R.L.I. is affected by neither the maturation time nor the $\mathrm{Ca}^{2+}$ content when $x$ is lower than $0.07 \mathrm{M} \mathrm{Ca}^{2+}$, as occurred on cit- $\mathrm{Ca}^{2+}: \mathrm{EuPO}_{4} \cdot \mathrm{nH}_{2} \mathrm{O}$, while the R.L.I. at $x=0.07 \mathrm{M}$ $\mathrm{Ca}^{2+}$ is high at short maturation time (due to the amorphous nature of the samples) and low at high maturation time (due to the crystalline nature of the sample and also due the higher citrate amount coating the raphdophane and vaterite nanoparticles). Concerning the luminescence properties in aqueous dispersion, neither $\mathrm{pH}$ nor ionic strength nor temperature affect their luminescence properties at physiological range.

According to all the above considerations the optimal conditions to synthesize cytocompatible cit-Ca ${ }^{2+}: \mathrm{TbPO}_{4} \cdot \mathrm{nH}_{2} \mathrm{O}$ nanocrystals free of vaterite or with negligible amount of this phase, with enough and exploitable luminescent properties (R.L.I and luminescent lifetimes) and higher stability of their aqueous suspensions at the $\mathrm{pH}$ range of biological interest (5-7.4), are when using $\mathrm{Ca}^{2+}$ doping concentration $x=0.01 \mathrm{M}$ and $x=0.03 \mathrm{M}$, at any of the maturation times from 4 to $96 \mathrm{~h}$.

Summing up, all the above properties are positive relative to the applications of these nanoparticles as luminescent labeling agents and highlight the potential of the thermal decomplexing synthetic method to prepare this kind of nanophosphors.

\section{Conclusions}

Cit- $\mathrm{Ca}^{2+}: \mathrm{TbPO}_{4} \cdot \mathrm{nH}_{2} \mathrm{O}$ nanocrystals of the hexagonal rhabdophane phase, with $\mathrm{n} \sim 0.9$ and tailored $\mathrm{Ca}^{2+}$ content between 0.42 and $8.11 \mathrm{wt} \%$ were successfully obtained by thermal decomplexing of $\mathrm{Ca}^{2+} / \mathrm{Tb}^{3+} /$ citrate/phosphate/carbonate solutions. These nanocrystals of about 29-37 $\mathrm{nm}$ are mainly monodomains and display basically isometric ill-defined morphologies, with $\mathrm{Ca}^{2+}$ having limited inhibiting/promoting effect on the growth of these nanoparticles, but enhancing the amount of citrate adsorbed on the surface in dosedepending manner. All the nanoparticles displayed high cytocompatibility on two human carcinoma cell lines and cell viability correlated positively with the amount of doping $\mathrm{Ca}^{2+}$.

Luminescence properties of the nanocrystals reveal that luminescent lifetimes increase (between $\sim 800$ and $\sim 2600 \mu$ s) by increasing the $\mathrm{Ca}^{2+}$ doping concentration. Their relative luminescence intensities in solid state (around 200 units) are affected by neither $\mathrm{Ca}^{2+}$, nor citrate content, nor maturation time for $\mathrm{Ca}^{2+}$ doping concentrations below $0.07 \mathrm{M} \mathrm{Ca}^{2+}$. Only at this doping concentration the maturation time strongly affects R.L.I, decreasing it. At low maturation times $(4 \mathrm{~h}, 24 \mathrm{~h}$ ) it is high (around 650 units). However, at $96 \mathrm{~h}$, it strongly decreases up to $\sim 40$. This finding was related to the amorphous nature of the precipitates obtained at 4 and $24 \mathrm{~h}$, whereas at $96 \mathrm{~h}$, the precipitates were crystalline. In addition, this sample also contains vaterite and a higher percent weight of citrate than the samples obtained with lower doping concentrations of $\mathrm{Ca}^{2+}$, and therefore it presents a lower percent weight of emissive material. In aqueous suspensions, neither $\mathrm{pH}$ nor ionic strength nor the temperature affect their luminescence properties.

According to all the above considerations, the optimal conditions to synthesize cytocompatible cit-Ca ${ }^{2+}: \mathrm{TbPO}_{4} \cdot \mathrm{nH}_{2} \mathrm{O}$ nanocrystals free of vaterite or with negligible amount of this phase, with enough and exploitable luminescent properties (R.L.I and luminescent 
lifetimes) and higher stability of their aqueous suspensions at the $\mathrm{pH}$ range of biological interest (5-7.4), are when using $\mathrm{Ca}^{2+}$ doping concentration $x=0.01 \mathrm{M}$ and $x=0.03 \mathrm{M}$, at any of the maturation times from 4 to $96 \mathrm{~h}$.

Summing up, the above properties are encouraging relative to the potential bioimaging applications of the nanocrystals. They can thus represent promising new luminescent nanoprobes for such applications and, if coupled with targeting and therapeutic moieties, they could be effective tools for theranostics.

Supplementary Materials: The following are available online at https://www.mdpi.com/2079 -4991/11/2/322/s1, Figure S1: Evolution of FTIR spectra with time of samples prepared with different $\mathrm{Ca}^{2+}$ doping concentrations $x=0.01$ to $0.07 \mathrm{M}$, Figure S2: Evolution of Raman spectra with time of samples prepared with different $\mathrm{Ca}^{2+}$ doping concentrations $x=0.01$ to $0.07 \mathrm{M}$, Figure S3: TGA analyses of precipitates obtained at $96 \mathrm{~h}$ from solutions with $\mathrm{Ca}^{2+}$ doping concentrations ranging from (a) $x=0.01$ to (d) $x=0.07 \mathrm{M}$, Figure S4: Cumulative volume oversize distribution of the cit- $\mathrm{Ca}^{2+}: \mathrm{TbPO}_{4} \cdot \mathrm{nH}_{2} \mathrm{O}$ nanocrystals prepared with $\mathrm{Ca}^{2+}$ doping concentrations $x=$ $0.01,0.03,0.05$ and $0.07 \mathrm{M}$ at 4, 24 and $96 \mathrm{~h}$, Figure S5: Excitation (dashed lines) and emission (solid lines) uncorrected spectra of solid cit-Ca ${ }^{2+}: \mathrm{TbPO}_{4} \cdot \mathrm{nH}_{2} \mathrm{O}$ samples prepared with $x=0.01 \mathrm{M} \mathrm{Ca}^{2+}$ at maturation times of $96 \mathrm{~h}$ using $\mathrm{t}_{\mathrm{d}}=120 \mu \mathrm{s}, \mathrm{t}_{\mathrm{d}}=5 \mathrm{~ms}$ and (a) $\lambda \mathrm{exc} / \mathrm{em}=230 / 545 \mathrm{~nm}$, slit width exc $/ \mathrm{em}=2.5 / 2.5 \mathrm{~nm}$, detector voltage $545 \mathrm{~V} ; \mathrm{b}$ ) $\lambda$ exc $/ \mathrm{em}=375 / 545 \mathrm{~nm}$, slit width exc $/ \mathrm{em}=5 / 5 \mathrm{~nm}$, detector voltage $470 \mathrm{v}$, Figure S6: Excitation (dashed lines) and emission (solid lines) uncorrected spectra of solid cit- $\mathrm{Ca}^{2+}: \mathrm{TbPO}_{4} \cdot \mathrm{nH}_{2} \mathrm{O}$ samples prepared with different $\mathrm{Ca}^{2+}$ doped concentration at maturation times of $4 \mathrm{~h}, 24 \mathrm{~h}, 96 \mathrm{~h}$ and 7 days, Figure S7: Variation of the R.L.I. of the solid cit-Ca ${ }^{2+}: \mathrm{TbPO}_{4} \cdot \mathrm{nH}_{2} \mathrm{O}$ samples at the maximum excitation and emission wavelengths at several $\mathrm{Ca}^{2+}$ concentrations when the maturation time is changed. Figure S8: Variation of the R.L.I. of the solid cit-Ca ${ }^{2+}: \mathrm{TbPO}_{4} \cdot \mathrm{nH}_{2} \mathrm{O}$ samples at the maximum excitation and emission wavelengths at several maturation time when the $\mathrm{Ca}^{2+}$ concentration is changed. Figure S9: Luminescence decay curve of different solid cit-Ca ${ }^{2+}: \mathrm{TbPO}_{4} \cdot \mathrm{nH}_{2} \mathrm{O}$ samples at maturation times of $96 \mathrm{~h}, \mathrm{t}_{\mathrm{d}}=100 \mu \mathrm{s}, \mathrm{t}_{\mathrm{g}}=0.01 \mathrm{~ms}$, $\lambda_{\text {exc } / \text { em }}=375 / 545 \mathrm{~nm}$, slit-widths $\mathrm{exc}_{\mathrm{em}}=10 / 10 \mathrm{~nm}$, and detector voltage $=600 \mathrm{~V}$. Circles correspond to experimental data (100 cycles) and lines to the fitting equation. Figure S10: Variation of the luminescence lifetime of the solid cit- $\mathrm{Ca}^{2+}: \mathrm{TbPO}_{4} \cdot \mathrm{nH}_{2} \mathrm{O}$ nanoparticles prepared at several $\mathrm{Ca}^{2+}$ concentrations when the maturation time is changed. Figure S11: Variation of the luminescence lifetime of the solid cit-Ca ${ }^{2+}: \mathrm{TbPO}_{4} \cdot \mathrm{nH}_{2} \mathrm{O}$ samples at several maturation times when the $\mathrm{Ca}^{2+}$ concentration. Figure S12: Effect of the ionic strength over the (a) R.L.I. and (b) luminescence lifetime of the cit- $\mathrm{Ca}^{2+}: \mathrm{TbPO}_{4} \cdot \mathrm{nH}_{2} \mathrm{O}$ samples at $96 \mathrm{~h}$ maturation time dispersed in aqueous media at several $\mathrm{Ca}^{2+}$ concentrations is changed. Figure S13. Effect of the temperature over the (a) R.L.I. and (b) luminescence lifetime of the cit- $\mathrm{Ca}^{2+}: \mathrm{TbPO}_{4} \cdot \mathrm{nH}_{2} \mathrm{O}$ samples at $96 \mathrm{~h}$ maturation time dispersed in aqueous media at several $\mathrm{Ca}^{2+}$ concentrations.

Author Contributions: Conceptualization, J.G.-M., D.C.-L., and M.P.; Investigation, J.G.-M., J.F.F.-S., M.P., I.R.-C., R.F.-P., A.D., and C.V.-E.; methodology, R.F.-P., A.D., J.F.F.-S., and C.V.-E; Supervision, J.G.-M.; writing-original draft preparation, J.G.-M. and M.P.; writing—review and editing, J.G.-M., M.P., and J.F.F.S.; funding acquisition, J.G.-M., D.C.-L. and M.P. All authors have read and agreed to the published version of the manuscript.

Funding: This research was funded by Spanish Agencia Estatal de Investigación of the Ministerio de Ciencia, Innovación y Universidades (MICIU) and co-funded with FEDER, UE, Project No. PGC2018102047-B-I00 (MCIU/AEI/FEDER, UE). J.F.F.-S. acknowledges the Spanish Ministerio de Economía y Competitividad Project No. CTQ2017-88079-P for support. M.P. acknowledges the Progetto di Ricerca Fondi di Ateneo per la Ricerca-FAR 2017 "Development of innovative biological materials for the functional regeneration of cardiac tissue models".

Acknowledgments: Authors acknowledge technical support of technician of the CIC of the University of Granada.

Conflicts of Interest: The authors declare no conflict of interest. 


\section{References}

1. Sreenivasan, V.K.A.; Zvyagin, A.V.; Goldys, E.M. Luminescent nanoparticles and their applications in the life sciences. J. Phys. Condens. Matter 2013, 25, 194101. [CrossRef] [PubMed]

2. Li, J.; Zhu, J.-J. Quantum dots for fluorescent biosensing and bio-imaging applications. Analyst 2013, 138, 2506. [CrossRef] [PubMed]

3. Fu, C.-C.; Lee, H.-Y.; Chen, K.; Lim, T.-S.; Wu, H.-Y.; Lin, P.-K.; Wei, P.K.; Tsao, P.H.; Chang, H.-C.; Fann, W. Characterization and application of single fluorescent nanodiamonds as cellular biomarkers. Proc. Natl. Acad. Sci. USA 2007, 104, 727-732. [CrossRef]

4. Yeh, Y.-C.; Creran, B.; Rotello, V.M. Gold nanoparticles: Preparation, properties, and applications in bionanotechnology. Nanoscale 2012, 4, 1871-1880. [CrossRef]

5. Wang, F.; Tan, W.B.; Zhang, Y.; Fan, X.P.; Wang, M.Q. Luminescent nanomaterials for biological labelling. Nanotechnology 2006, 17, R1-R13. [CrossRef]

6. Oltolina, F.; Gregoletto, L.; Colangelo, D.; Gómez-Morales, J.; Delgado-López, J.M.; Prat, M. Monoclonal antibody-targeted fluorescein-5-isothiocyanate-labeled biomimetic nanoapatites: A promising fluorescent probe for imaging applications. Langmuir 2015, 31, 1766-1775. [CrossRef] [PubMed]

7. Neacsu, I.A.; Stoica, A.E.; Vasile, B.S.; Andronescu, E. Luminescent hydroxyapatite doped with rare earth elements for biomedical applications. Nanomaterials 2019, 9, 239. [CrossRef]

8. Gómez-Morales, J.; Verdugo-Escamilla, C.; Fernández-Penas, R.; Parra-Milla, C.M.; Drouet, C.; Maube-Bosc, F.; Oltolina, F.; Prat, M.; Fernández-Sánchez, J.F. Luminescent biomimetic citrate-coated europium-doped carbonated apatite nanoparticles for use in bioimaging: Physico-chemistry and cytocompatibility. RSC Adv. 2018, 8, 2385-2397. [CrossRef]

9. Derfus, A.M.; Chan, W.C.W.; Bhatia, S.N. Probing the cytotoxicity of semiconductor quantum dots. Nano Lett. 2004, 4, 11-18. [CrossRef]

10. Fang, Y.-P.; Xu, A.-W.; Song, R.-Q.; Zhang, H.-X.; You, L.-P.; Yu, J.C.; Liu, H.-Q. Systematic synthesis and characterization of single-crystal lanthanide orthophosphate nanowires. JACS 2003, 125, 16025-16034. [CrossRef]

11. Luo, Q.; Shen, S.; Lu, G.; Xiao, X.; Mao, D.; Wang, Y. Synthesis of cubic ordered mesoporous YPO4: $\operatorname{Ln}^{3+}$ and their photoluminescence properties. J. Mater. Chem. 2009, 19, 8079-8085. [CrossRef]

12. Zhang, F.; Wong, S.S. Ambient large-scale template-mediated synthesis of high-aspect ratio single-crystalline, chemically doped rare-earth phosphate nanowires for bioimaging. ACS Nano 2010, 4, 99-112. [CrossRef] [PubMed]

13. Di, W.; Li, J.; Shirahata, N.; Sakka, Y.; Willingere, M.-G.; Pinna, N. Photoluminescence, cytotoxicity and in vitro imaging of hexagonal terbium phosphate nanoparticles doped with europium. Nanoscale 2011, 3, 1263-1269. [CrossRef]

14. Ito, H.; Fujishiro, Y.; Sato, T.; Okuwaki, A. Preparation of lanthanide orthophosphates by homogeneous precipitation under hydrothermal conditions using lanthanide-EDTA chelates. Br. Ceram. Trans. 1995, 94, 146-150.

15. Zollfrank, C.; Scheel, H.; Brungs, S.; Greil, P. Europium(III) orthophosphates: Synthesis, characterization, and optical properties. Cryst. Growth Des. 2008, 8, 766-770. [CrossRef]

16. Iafisco, M.; Delgado-López, J.M.; Varoni, E.M.; Tampieri, A.; Rimondini, L.; Gómez-Morales, J.; Prat, M. Cell surface receptor targeted biomimetic apatite nanocrystals for cancer therapy. Small 2013, 9, 3834-3844. [CrossRef]

17. Iafisco, M.; Marchetti, M.; Gómez-Morales, J.; Hernández-Hernández, M.A.; García-Ruiz, J.M.; Roveri, N. Silica gel template for calcium phosphates crystallization. Cryst. Growth Des. 2009, 9, 4912-4921. [CrossRef]

18. Ramírez-Rodríguez, G.B.; Delgado López, J.M.; Gómez-Morales, J. Evolution of calcium phosphate precipitation in hanging drop vapor diffusion by in situ Raman microspectroscopy. CrystEngComm 2013, 15, 2206-2212. [CrossRef]

19. Bu, W.; Zhang, L.; Hua, Z.; Chen, H.; Shi, J. Synthesis and characterization of uniform spindle-shaped microarchitectures self-assembled from aligned single-crystalline nanowires of lanthanum phosphates. Cryst. Growth Des. 2007, 7, $2305-2309$. [CrossRef]

20. Fang, Y.-P.; Xu, A.-W.; Dong, W.-F. Highly improved green photoluminescence from $\mathrm{CePO}_{4}: \mathrm{Tb} / \mathrm{LaPO} 4$ core/shell nanowires. Small 2005, 1, 967-971. [CrossRef]

21. Nuñez, N.O.; Liviano, S.R.; Ocaña, M.J. Citrate mediated synthesis of uniform monazite $\mathrm{LnPO}_{4}(\mathrm{Ln}=\mathrm{La}, \mathrm{Ce})$ and $\mathrm{Ln}: \mathrm{LaPO} 4$ $(\mathrm{Ln}=\mathrm{Eu}, \mathrm{Ce}, \mathrm{Ce}+\mathrm{Tb})$ spheres and their photoluminescence. Colloid Interface Sci. 2010, 349, 484-491. [CrossRef]

22. Patra, C.R.; Bhattacharya, R.; Patra, S.; Basu, S.; Mukherjee, P.; Mukhopadhyay, D. Inorganic phosphate nanorods are a novel fluorescent label in cell biology. J. Nanobiotechnol. 2006, 4, 11. [CrossRef]

23. Yu, C.; Yu, M.; Li, C.; Liu, X.; Yang, J.; Yang, P.; Lin, J. Facile sonochemical synthesis and photoluminescent properties of lanthanide orthophosphate nanoparticles. J. Solid State Chem. 2009, 182, 339-342. [CrossRef]

24. Wang, X.; Gao, M. A facile route for preparing rhabdophane rare earth phosphate nanorods. J. Mater. Chem. 2006, 16, 1360-1365. [CrossRef]

25. Hou, Z.; Wang, L.; Lian, H.; Chai, R.; Zhang, C.; Cheng, Z.; Lin, J. Preparation and luminescence properties of Ce $\mathrm{e}^{3+}$ and/or Tb $\mathrm{Cb}^{3+}$ doped $\mathrm{LaPO}_{4}$ nanofibers and microbelts by electrospinning. J. Solid State Chem. 2009, 182, 698-708. [CrossRef]

26. Xing, Y.; Li, M.; Davis, S.A.; Mann, S. Synthesis and characterization of cerium phosphate nanowires in microemulsion reaction media. J. Phys. Chem. B 2006, 110, 1111-1113. [CrossRef]

27. Liu, X.; Wang, Q.; Gao, Z.; Sun, J.; Shen, J. Fabrication of lanthanide phosphate nanocrystals with well-controlled morphologies by layer-by-layer adsorption and reaction method at room temperature. Cryst. Growth Des. 2009, 9, 3707-3713. [CrossRef] 
28. Huong Tran, T.; Anh Tran, K.; Khuyen Hoang, T.; Hien Pham, T.; Minh Le, Q. Fabrication and properties of terbium phosphate nanorods. Adv. Nat. Sci. Nanosci. Nanotechnol. 2012, 3, 015010. [CrossRef]

29. Gómez-Morales, J.; Verdugo-Escamilla, C.; Fernández-Penas, R.; Parra-Milla, C.M.; Drouet, C.; Iafisco, M.; Oltolina, F.; Prat, M.; Fernández-Sánchez, J.F. Bioinspired crystallization, sensitized luminescence and cytocompatibility of citrate-functionalized Ca-substituted europium phosphate monohydrate nanophosphors. J. Colloid Interface Sci. 2019, 538, 174-186. [CrossRef]

30. López-Macipe, A.; Gómez-Morales, J.; Rodríguez-Clemente, R. Nanosized hydroxyapatite precipitation from homogeneous calcium/citrate/phosphate solutions using microwave and conventional heating. Adv. Mater. 1998, 10, 49-53. [CrossRef]

31. Delgado-López, J.M.; Iafisco, M.; Rodríguez, I.; Prat, M.; Gómez-Morales, J.; Tampieri, A. Crystallization of bioinspired citratefunctionalized nanoapatites with tailored carbonate content. Acta Biomater. 2012, 8, 3491-3499. [CrossRef]

32. Martínez-Casado, F.J.; Iafisco, M.; Delgado-López, J.M.; Martínez-Benito, C.; Ruiz-Pérez, C.; Colangelo, D.; Oltolina, F.; Prat, M.; Gómez-Morales, J. Bioinspired citrate-apatite nanocrystals doped with divalent transition metal ions. Cryst. Growth Des. 2016, 1, 145-153. [CrossRef]

33. Delgado-López, J.M.; Frison, R.; Cervellino, A.; Gómez-Morales, J.; Guagliardi, A.; Masciocchi, N. Crystal size, morphology, and growth mechanism in bio-inspired apatite nanocrystals. Adv. Funct. Mater. 2014, 24, 1090-1099. [CrossRef]

34. Hu, Y.Y.; Rawal, A.; Schmidt-Rohr, K. Strongly bound citrate stabilizes the apatite nanocrystals in bone. Proc. Natl. Acad. Sci. USA 2010, 107, 22425-22429. [CrossRef]

35. Coelho, A.A. TOPAS and TOPAS-Academic: An optimization program integrating computer algebra and crystallographic objects written in C++. J. Appl. Cryst. 2018, 51, 210-218. [CrossRef]

36. Combes, C.; Bareille, R.; Rey, C. Calcium carbonate-calcium phosphate mixed cement compositions for bone reconstruction. J. Biomed. Mater. Res. Part A 2006, 79, 318-328. [CrossRef]

37. Young, R.A. Introduction to the Rietveld method. In The Rietveld Method; Young, R.A., Ed.; Oxford University Press: Oxford, UK, 1993; pp. 1-38.

38. Clavier, N.; del Mesbah, A.; Szenknect, S.; Dacheux, N. Monazite, rhabdophane, xenotime \& churchite: Vibrational spectroscopy of gadolinium phosphate polymorphs. Spectrochim. Acta Part A Mol. Biomol. Spectrosc. 2018, 205, 85-94. [CrossRef]

39. Assaaoudi, H.; Ennaciri, A.; Rulmont, A. Vibrational spectra of hydrated rare earth orthophosphates. Vibrat. Spectr. 2001, 2, 81-90. [CrossRef]

40. Donnelly, F.C.; Purcell-Milton, F.; Framont, V.; Cleary, O.; Dunne, P.W.; Gun'k, Y.K. Synthesis of CaCO 3 nano- and micro-particles by dry ice carbonation. Chem. Commun. 2017, 53, 6657-6660. [CrossRef] [PubMed]

41. Tada, H.; Bronkema, J.L.; Bell, A. Application of in situ surface-enhanced Raman spectroscopy (SERS) to the study of citrate oxidation on silica-supported silver nanoparticles. Catal. Lett. 2004, 92, 93-99. [CrossRef]

42. Lucas, S.; Champion, E.; Bernache-Assollant, D.; Leroy, G. Rare earth phosphate powders $\operatorname{RePO}_{4} \cdot \mathrm{nH}_{2} \mathrm{O}(\mathrm{Re}=\mathrm{La}, \mathrm{Ce}$ or Y) II. Thermal behavior. J. Solid State Chem. 2004, 177, 312-1320. [CrossRef]

43. Cho, J.; Kim, C.H. Solid-state phase transformation mechanism from hexagonal $\mathrm{GdPO}_{4}: \mathrm{Eu}^{3+}$ nanorods to monoclinic nanoparticles. RSC Adv. 2014, 4, 31385-31392. [CrossRef]

44. Kijkowska, R. Thermal decomposition of lanthanide orthophosphates synthesized through crystallisation from phosphoric acid solution. Thermochim. Acta 2003, 404, 81-88. [CrossRef]

45. Colomer, M.T.; Delgado, I.; Ortiz, A.L.; Fariñas, J.C. Microwave-assisted hydrothermal synthesis of single-crystal nanorods of rhabdophane-type Sr-doped $\mathrm{LaPO}_{4} \cdot \mathrm{nH}_{2}$ O. J. Am. Ceram. Soc. 2014, 97, 750-758. [CrossRef]

46. Jabalera, Y.; Oltolina, F.; Prat, M.; Jimenez-Lopez, C.; Fernández-Sánchez, J.F.; Choquesillo-Lazarte, D.; Gómez-Morales, J. EuDoped Citrate-Coated Carbonated Apatite Luminescent Nanoprobes for Drug Delivery. Nanomaterials 2020, 10, 199. [CrossRef]

47. Lundqvist, V.; Stigler, J.; Elia, G.; Lynch, I.; Cedervall, T.; Dawson, K.A. Nanoparticle size and surface properties determine the protein corona with possible implications for biological impacts. Proc. Natl. Acad. Sci. USA 2008, 105, 14265-14270. [CrossRef]

48. Hemmilä, I.; Dakubu, S.; Mukkala, V.-M.; Siitari, H.; Lövgren, T. Europium as a label in time-resolved immunofluorometric assays. Anal. Biochem. 1984, 137, 335. [CrossRef]

49. Siqueira, K.P.F.; Lima, P.P.; Ferreira, R.A.S.; Carlos, L.D.; Bittar, E.M.; Matinaga, F.M.; Paniago, R.; Krambrock, K.; Moreira, R.L.; Dias, A.J. Influence of the Matrix on the Red Emission in Europium Self-Activated Orthoceramics. Phys. Chem. C 2015, 119, 17825. [CrossRef]

50. Siqueira, K.P.F.; Lima, P.P.; Ferreira, R.A.S.; Carlos, L.D.; Bittar, E.M.; Granado, E.; González, J.C.; Abelenda, A.; Moreira, R.L.; Dias, A. Lanthanide Orthoantimonate Light Emitters: Structural, Vibrational, and Optical Properties. Chem. Mater. 2014, $26,6351$. [CrossRef]

51. Medina-Velazquez, D.Y.; Caldiño, U.; Morales-Ramirez, A.; Reyes-Miranda, J.; López, R.E.; Escudero, R.; Ruiz-Guerrero, R.; Morales Perez, M.F. Synthesis of luminescent terbium-thenoyltriflouroacetone MOF nanorods for green laser application. Opt. Mater. 2019, 87, 3-10. [CrossRef]

52. Richardson, F.S. Terbium(III) and europium(III) ions as luminescent probes and stains for biomolecular systems. Chem. Rev. 1982, 82, 541. [CrossRef]

53. Guilbault, G.G. General Aspects of Luminescence Spectroscopy, Practical Fluorescence; Guilbault, G.G., Ed.; Marcel Dekker: New York, NY, USA, 1990.

54. ISO 10993-5 Biological Evaluation of Medical Devices Part 5: Tests for In Vitro Cytotoxicity; International Standard Organization: Geneva, Switzerland, 2009. 
55. López-Macipe, A.; Gómez-Morales, J.; Rodriguez-Clemente, R. The role of $\mathrm{pH}$ in the adsorption of citrate ions on hydroxyapatite. J. Colloid Interface Sci. 1998, 200, 114-120. [CrossRef]

56. Borroni, E.; Miola, M.; Ferraris, S.; Ricci, G.; Žužek Rožman, K.; Kostevšek, N.; Catizone, A.; Rimondini, L.; Prat, M.; Verné, E.; et al. Tumor targeting by lentiviral vectors combined with magnetic nanoparticles in mice. Acta Biomater. 2017, 59, 303-316. [CrossRef] [PubMed]

57. Mooney, C.L. X-ray diffraction study of cerium phosphate and related crystals. I. Hexagonal modification. Acta Cryst. 1950, 3, 337-340. [CrossRef] 